CUADERNOS DE ESTUDIOS GALLEGOS, LIX Núm. 125 (enero-diciembre 2012), págs. 193-232

ISSN: 0210-847 X

DOI: $10.3989 /$ ceg.2012.125.08

\title{
ALFABETIZACIÓN, AUTORÍA E PRODUCIÓN IMPRESA. UNHA APROXIMACIÓN EN FEMININO Á CULTURA LETRADA DA GALICIA MODERNA
}

Miguel García-FernándeZ

Universidade de Santiago de Compostela 


\section{ALFABETIZACIÓN, AUTORÍA E PRODUCIÓN IMPRESA. UNHA APROXIMACIÓN EN FEMININO Á CULTURA LETRADA DA GALICIA MODERNA}

RESUMO:

O presente artigo ten por obxectivo fundamental contribuír ao mellor coñecemento da situación das mulleres na Galicia moderna a través dunha primeira aproximación ás complexas relacións que xurdiron entre estas e a cultura escrita. Para isto, procederase a esbozar o marco historiográfico, así como unha contextualización global na que se terán en conta as numerosas posibilidades e dificultades que tiveron as mulleres para acceder á cultura letrada, así como a súa participación na produción intelectual e física dos impresos galegos. Deste modo, unha revisión da bibliografía recente sobre o tema permitirá observar a existencia dunha gran diversidade de situacións, entre as que convén destacar as altas taxas de analfabetismo feminino, as dificultades para que os discursos elaborados por mulleres chegaran a converterse en textos impresos e a participación laboral dun reducido número de mulleres galegas na imprenta.

PalABRAS ClAVE: Historia das mulleres, Historia cultural, Galicia Moderna, Alfabetización, Autoría, Imprenta.

\section{ALFABETIZACIÓN, AUTORÍA Y PRODUCCIÓN IMPRESA. UNA APROXIMACIÓN EN FEMENINO A LA CULTURA LETRADA DE LA GALICIA MODERNA}

\section{RESUMEN:}

El presente artículo tiene por objetivo fundamental contribuir al mejor conocimiento de la situación de las mujeres en la Galicia moderna a través de una primera aproximación a las complejas relaciones que surgieron entre éstas y la cultura escrita. Para ello, se procederá a esbozar el marco historiográfico, así como una contextualización global en la que se tendrán en cuenta las numerosas posibilidades y dificultades que tuvieron las mujeres para acceder a la cultura letrada, así como su participación en la producción intelectual y física de los impresos gallegos. De este modo, una revisión de la bibliografía reciente sobre el tema permitirá observar la existencia de una gran diversidad de situaciones, entre las que conviene destacar las altas tasas de analfabetismo femenino, las dificultades para que los discursos elaborados por mujeres llegasen a convertirse en textos impresos y la participación laboral de un reducido número de mujeres gallegas en la imprenta.

PalABRAS ClAVE: Historia de las mujeres, Historia cultural, Galicia Moderna, Alfabetización, Autoría, Imprenta.

\section{TEACHING OF BASIC LITERACY, AUTHORSHIP AND PRINTED PRODUCTION. \\ A FEMININE RAPPROCHEMENT TO LEARNED CULTURE IN EARLY MODERN GALICIA}

\section{ABSTRACT:}

This article attempts to promote a better understanding of early modern Galician women's situation through an initial rapprochement to the complex connections between written culture and them. In order to achieve this, we will outline the historiographical framework, as well as a global context in which we will take into account the possibilities and difficulties that women had to gain access to learned culture, together with their participation in the intellectual and physical production of Galician printed works. Consequently, a revision of the latest bibliography about this topic will allow us to observe a great variety of situations; such as the high rate of women's illiteracy, the problems to turn females' discourses into printed texts and the development of printing jobs by a small number of Galician women.

KEY WORDS: Women's History, Cultural History, Early Modern Galicia, Teaching of Basic Literacy, Authorship, Printing. 
Recibido/Received: 26/06/2012

Aceptado/Accepted: 14/08/2012

o longo dos últimos trinta anos, a Historia das mulleres e das relacións
de xénero ten abordado numerosas cuestións que poñen de manifesto a
necesidade de tomar en consideración ás mulleres, non só como obxecto de estudo por parte dos investigadores, senón tamén como suxeitos da Historia. Talvez unha das preocupacións máis recentes sobre o tema consiste en perfilar as complexas relacións que xurdiron entre o sector feminino da poboación e a cultura $^{1}$. Deste modo, dende diferentes perspectivas insístese en cuestións como as posibilidades que se lles ofreceron ás mulleres para acceder a unha educación máis ou menos regulamentada ou a súa capacidade para crear e divulgar discursos propios nunha sociedade na que o dominio sobre a palabra escrita era algo maioritariamente masculino. Neste sentido, queremos ofrecer aquí unha primeira aproximación ao conxunto de relacións que podemos establecer entre as mulleres e a cultura letrada ao longo dos séculos XVI, XVII e XVIII, contextualizándoas nun marco global no que convén diferenciar dous grandes fenómenos: a aprendizaxe, que lles permitiría acceder ás diversas manifestacións da cultura letrada e colaborar na súa elaboración intelectual, así como a participación feminina na produción impresa, non só mediante a autoría, senón tamén a través do seu papel na historia da imprenta. Estes fenómenos encadraranse no espazo galego, caracterizado polo seu "atraso cultural", derivado da confluencia de factores moi diversos: a súa situación periférica, as malas comunicacións terrestres, a dispersión da poboación, a debilidade do fenómeno urbano, o carácter rural da meirande parte da poboación, a pobreza das súas xentes, a constante

\footnotetext{
${ }^{1}$ O presente artigo ten a súa orixe no Traballo Academicamente Dirixido As mulleres a través dos impresos galegos dos séculos XVI, XVII e XVIII, realizado durante o curso académico 2010/2011, baixo a dirección da Dra. Ofelia Rey Castelao á que, dende estas liñas, agradezo a súa axuda e interese. Todo o relativo ás imaxes e arquetipos femininos que aparecen rexistrados nos impresos galegos analizados, procedentes na súa meirande parte da Biblioteca Xeral da Universidade de Santiago de Compostela, será publicado noutra ocasión.
} 
dependencia cultural, o afastamento da elite nobiliaria e, consecuentemente, do seu padroádego, etc. ${ }^{2}$

Tras presentar un breve estado da cuestión sobre as principais investigacións que se teñen levado a cabo na historiografía modernista galega en relación cos ámbitos da historia das mulleres e da cultura letrada, procederemos a estudar a primeira das relacións que podemos establecer entre as mulleres e os impresos saídos dos talleres "asentados" en Galicia: a alfabetización feminina. A lectura preséntase como unha destreza indispensable para o establecemento destas relacións xa que, máis alá das posibilidades que puideron ter para acceder aos contidos destes impresos e, en xeral, de tódalas manifestacións da cultura escrita a través da súa lectura pública, a lectura persoal sería o mellor enlace entre as mulleres e a imprenta; de feito, as taxas de alfabetización darannos o número potencial de lectoras. Na segunda parte deste traballo, analizaremos o papel das mulleres como produtoras, vendedoras, creadoras e promotoras da produción impresa. Apenas nos podemos nutrir dun conxunto de noticias puntuais e dispersas pero, cando menos, permiten identificar en Galicia pautas de comportamento xa coñecidas para outros espazos da Monarquía Hispánica. Trátase, en definitiva, dunha aproximación inicial ao tema sen máis pretensións que as de esbozar unha imaxe global sobre as relacións (activas e pasivas) que se estableceron entre as mulleres e a cultura letrada (particularmente a impresa) no marco da Galicia Moderna, insistindo sempre nos problemas e límites atopados nas fontes e na bibliografía.

Nos últimos anos, a historiografía modernista galega e, en particular, a impulsada dende a Área de Historia Moderna da Universidade de Santiago de Compostela ten incorporado ao seu quefacer investigador o interese por recuperar a historia das mulleres da Época Moderna. Neste labor cómpre destacar as contribucións de Ofelia Rey Castelao, tanto no que se refire á investigación directa como á dirección de traballos sobre o tema, así como as debidas a Serrana Rial García ${ }^{3}$. Pero, antes desta integración consciente da perspectiva de xénero,

2 Ofelia Rey Castelao, Libros e lectura en Galicia. Siglos XVI-XIX, Santiago de Compostela, Xunta de Galicia, 2003, páx. 17.

3 Autoras de dúas monografías recentes sobre o tema: Historia de las mujeres en Galicia (siglos XVI al XIX), Vigo, Nigratrea, 2009 e Historia das mulleres en Galicia. Idade Moderna, Santiago de Compostela, Nigratrea, 2010. Por outra parte, destacan unha serie de balances historiográficos realizados por Ofelia REY CASTELAO, a través dos cales podemos seguir con precisión a evolución da investigación histórica sobre as mulleres no marco do modernismo galego: "Mujer y sociedad en la Galicia del Antiguo Régimen”, Obradoiro de Historia Moderna, 3 (1994), páxs. 51-69; "Las mujeres en la Galicia de la Edad Moderna: algunas consideraciones sobre su estudio", en Carlos Andrés GonzÁlez Paz (ed.), As voces de Clío: a palabra e a memoria da muller na Galicia, Santiago de Compostela, Instituto de Estudos Galegos "Padre Sarmiento", 2009, páxs. 65-86 e "La historia de las mujeres en Galicia: un estado de la cuestión (1988-2008)”, Minius, 17 (2009), páxs. 191-234. 
as numerosas contribucións do modernismo galego ao mellor coñecemento da realidade demográfica, económica e social do país permitiron poñer á luz comportamentos e circunstancias que afectaban directamente ao sector feminino da poboación. Neste sentido, os estudos sobre as estruturas familiares e sobre os modelos de transmisión e sucesión hereditarias marcaron a pauta de inicio para achegármonos á realidade social das mulleres ${ }^{4}$.

A partir dos anos '90 do século pasado, xurdiron as investigacións dedicadas especificamente ao tema das mulleres, nas que se procedeu a unha relectura en clave de xénero das numerosas fontes documentais conservadas. Froito deste labor apareceron diversos traballos, como os da xa mencionada Serrana Rial García ; algúns de Domingo L. González Lopo dende a historia das mentalida$\operatorname{des}^{6}$ ou varios de Ofelia Rey Castelao ${ }^{7}$. A eles habería que engadir outros estudos que, dende presupostos non sempre dependentes da historia de xénero, tamén contribuíron a avanzar no coñecemento das comunidades monásticas femininas, as nobres, as fidalgas, as burguesas, as artesás, as campesiñas, as pescadoras ou as marxinadas ${ }^{8}$.

\footnotetext{
${ }^{4}$ Destaca, por exemplo, o estudo pioneiro de Camilo Fernández Cortizo, "A una misma mesa y manteles: la familia en Tierra de Montes en el s. XVIII", Cuadernos de Estudios Gallegos, 33, 98 (1982), páxs. 237-276. Este mesmo autor reafirmou a importancia da perspectiva de xénero, agora xa perfectamente consolidada, en "Mujer, vejez y grupo doméstico en la Galicia rural meridional a finales del Antiguo Régimen", Nuevo Mundo, Mundos Nuevos [en liña], dispoñible en <http:// nuevomundo.revues.org/29553> [Consulta: 12/10/2010]. Dende a demografía histórica, vid. Isidro Dubert García, Historia de la familia en Galicia, 1550-1830, Sada, Ediciós do Castro, 1992.

5 Dende a súa tese de doutoramento, Mujer y actividad económica en la Galicia moderna: la inserción de las mujeres en la producción económica rural y urbana, [CD Rom], Santiago de Compostela, Universidade de Santiago de Compostela, 2003, até moitas outras contribucións como "Casar doncellas pobres, paradigma de la caridad eclesiástica", Obradoiro de Historia Moderna, 3 (1994), páxs. 71-85 ou "Solas y pobres: las mujeres de las ciudades de Galicia ante la marginalidad y la pobreza", Semata, 16 (2004), páxs. 301-331.

${ }^{6}$ Como "La religiosidad femenina en la Galicia de la Época Moderna", en Xavier CAstro e Jesús DE Juana (dirs.), A muller na historia de Galicia, Ourense, Deputación Provincial de Ourense, 1995, páxs. 67-91.

${ }^{7}$ Traballos que se consolidaron definitivamente ao longo da última década e que, actualmente, contan cun importante volume e dinamismo. Entre as contribucións máis recentes podemos mencionar dous traballos de Ofelia Rey CASTELAO, "Amour divin et amour mondain: 1'expérience des femmes mariées et des veuves en religion dans la Galice moderne", en Maurice Daumas (dir), Amour divin, amour mondain dans les écrits du for privé de la fin du Moyen Âge à 1914, Pau, Cairn, 2011, páxs. 237-254 ou "Las mujeres en la Galicia moderna: lo que sabemos y no sabemos de ellas", en Miguel García-Fernández, Silvia Cernadas Martínez e Aurora Ballesteros Fernández (eds.), As mulleres na Historia de Galicia. Actas do I Encontro Interdisciplinar de Historia de Xénero, Santiago de Compostela, Andavira, 2012, páxs. 117-139.

${ }^{8}$ Para un balance do modernismo galego onde se recollen todas estas contribucións, vid. Roberto J. LÓPEZ LóPeZ e Domingo L. González Lopo (eds.), Balance de la historiografía modernista (19732001). Actas del VI Coloquio de Metodología Histórica Aplicada (Homenaje al Profesor Dr. D.
} 
En canto á historia da educación e da cultura, vista dende a perspectiva das mulleres, ademais das investigacións realizadas por Margarita Sanz sobre a alfabetización e a escolarización na provincia de Pontevedra e a Compañía de María ${ }^{9}$, está en curso de redacción a tese de Ana María Sixto Barcia, que, sen dúbida, contribuirá a ofrecer novos datos e reflexións sobre as relacións das mulleres coa cultura letrada. Novamente, tamén debemos ter en conta aquí a existencia doutros traballos realizados dende presupostos metodolóxicos diversos, pero que teñen ofrecido numerosos datos sobre o alcance da alfabetización feminina ${ }^{10}$.

Ante o panorama historiográfico existente en Galicia, non podemos deixar de ser optimistas, xa que, en dúas décadas, logrouse o obxectivo principal procurado pola historia das mulleres: a conversión destas en obxecto de estudo histórico por parte das/os historiadoras/es e o seu recoñecemento como suxeitos axentes da historia. Ademais, cómpre sinalar que un estudo comparativo entre o feito aquí e o que atopamos na restante produción historiográfica desenvolvida dentro do Estado español, resólvese satisfactoriamente en prol do primeiro. Galicia non foi pioneira nin, unha vez implantada, fixo da historia das mulleres unha bandeira; porén, as investigacións de base realizadas dende os anos '70, xunto co impulso dunha serie de investigadoras comprometidas co tema, desembocaron en excelentes resultados que tamén contribuíron a enriquecer a bibliografía consagrada ao estudo da historia das mulleres na España moderna ${ }^{11}$. Talvez no ámbito no que máis carencias podemos atopar é precisamente no do presente traballo: a acceso e as relacións das mulleres coa cultura escrita. De todos modos, tendo

Antonio Eiras Roel) celebrado en Santiago de Compostela, del 25 al 27 de octubre de 2001, Santiago de Compostela, Xunta de Galicia, 2003. Tamén acaba de ser publicada unha síntese sobre a historia moderna de Galicia, que revela a importante participación das mulleres na sociedade galega dos séculos XVI, XVII e XVIII, coñecida grazas a todo este conxunto de investigacións, vid. Isidro Dubert García (coord.), Historia de la Galicia moderna, Santiago de Compostela, Universidade de Santiago de Compostela, 2012.

9 Margarita SAnz GonzÁLEz, "Alfabetización y escolarización en Galicia a fines del Antiguo Régimen”, Obradoiro de Historia Moderna, 1 (1992), páxs. 229-249 e "La Compañía de María en Galicia desde fines del Antiguo Régimen hasta la Primera República", en Actas del I Congreso Internacional del monacato femenino en España, Portugal y América. 1492-1992, León, Universidad de León, 1993, tomo II, páxs. 587-601.

10 Entre eles o de Antón Costa Rico, Historia da educación e da cultura en Galicia (séculos IVXX). Permanencias e cambios no contexto cultural e educativo europeo, Vigo, Xerais, 2004.

${ }_{11}$ Un amplo dossier bibliográfico, aínda que necesitado de actualización, é o de Mónica BoluFer Peruga, "Historia de las mujeres en la época moderna: selección de la bibligrafía reciente", Cuadernos de Historia Moderna, 19 (1997), páxs. 197-224. Tamén é preciso destacar o segundo volume da Historia de las mujeres en España y América Latina, dirixida pola Dra. Isabel MoranT, dedicado a "El mundo moderno", xa que nel sintetízanse gran parte dos coñecementos adquiridos até o momento tralos esforzos investigadores realizados nas últimas décadas. 
sempre en conta as particularidades de Galicia como espazo periférico, semella que os comportamentos culturais femininos non eran radicalmente diferentes aos que atopamos noutros espazos xeográficos.

Máis alá da historia das mulleres, outro dos temas que adquiriu certo desenvolvemento no modernismo galego foi o estudo da cultura escrita no marco da historia cultural e, ao mesmo tempo, da historia das mentalidades. Dous ámbitos de traballo que acolleron no seu seo todo un conxunto de investigacións sobre as actitudes ante a morte, o asociacionismo relixioso, as devocións, a reforma dos comportamentos morais e relixiosos, a ensinanza, as prácticas lectoras ou a historia das festas e das cerimonias políticas. Nalgúns destes temas diferenciáronse os comportamentos de homes e mulleres e, por exemplo, no caso das devocións relixiosas, púidose comprobar a importancia de determinadas figuras femininas como obxecto de veneración a través de indicadores como a onomástica, a distribución da esmola ou a titularidade das confrarías e das ermidas ${ }^{12}$.

No relativo á ensinanza, diversas investigacións realizadas dende os anos ' 80 do século pasado teñen insistido en dous ámbitos: os niveis de alfabetización e as institucións que contribuíron á súa mellora (as escolas de primeiras letras, as escolas de gramática e as universidades) $)^{13}$. Para coñecer o primeiro destes aspectos, considerouse que as sinaturas, especialmente as rexistradas nas compravendas, eran un indicador válido ${ }^{14}$. Non obstante, as reservas que nos suscitan son moitas xa que, como se ten sinalado en repetidas ocasións, os individuos podían chegar a memorizar unha determinada sinatura sen que por iso dominasen a capacidade de ler ou escribir. No tocante ás institucións de ensinanza, téñense realizado avances parciais no coñecemento dos seus diferentes niveis, aínda que quedan moitos datos por coñecer sobre as escolas de primeiras letras, como o seu número, funcionamento e alumnado. Porén, isto non debe levarnos a pensar que só existiu a educación formalizada.

Outro dos grandes temas da historia da cultura foi o dos libros e a lectura. Tras unha primeira etapa na que primou o quefacer erudito arredor de cuestións como a imprenta ${ }^{15}$, estudos máis recentes puxeron de manifesto novas posibilidades de análise para esta liña de investigación. Tralas contribucións iniciais

\footnotetext{
12 Domingo L. González Lopo e Roberto J. López López, "Investigaciones sobre la historia de la cultura y de las mentalidades en la Galicia de la Edad Moderna", en R. J. López López e D. L. GonZÁLEZ Lopo (eds.), Balance de la historiografía modernista..., páxs. 102 e 107.

13 D. L. GonZÁlez Lopo, e R. J. López López, “Investigaciones sobre la historia...”, páxs. 111-116.

14 Ofelia Rey Castelao, "Niveles de alfabetización en la Galicia de fines del Antiguo Régimen", Bulletin Hispanique, 100, 2 (1998), páx. 283.

${ }^{15}$ Neste sentido destacan as contribución de Manuel Murguía, Manuel Soto Freire, Antonio López Ferreiro, Atanasio López, Carlos Martínez-Barbeito, Fermín Bouza Brey ou Antonio Odriozola e Xosé Ramón Barreiro Fernández.
} 
de Juan E. Gelabert ${ }^{16}$ e Baudilio Barreiro Mallón ${ }^{17}$, foi novamente Ofelia Rey Castelao quen máis avanzou nesta liña, especialmente coa monografía Libros y lectura en la Galicia moderna. Siglos XVI-XIX, onde recolle unha exhaustiva análise sobre a alfabetización, os tamaños e contidos de diversas bibliotecas particulares e institucionais ou a produción e comercialización de impresos en Galicia. Trátase dun estudo no que a pobreza da produción escrita aparece contextualizada no seo dunha sociedade na que só unha minoría sabía ler. Dentro desta, só uns poucos accederían á posesión ou consulta de libros e, deles, aínda menos chegarían a desenvolver unha práctica lectora habitual. A isto habería que engadir o aínda máis reducido número de autores e que, destes, só algúns, os menos, lograrían ver impresos os seus produtos. Movémonos, pois, por un conxunto de esferas nas que, aplicando a perspectiva de xénero, as mulleres serían a minoría das minorías.

Sen dúbida, a chegada da imprenta supuxo unha serie de transformacións culturais que marcaron un profundo cambio nas posibilidades de acceso á cultura escrita. Fronte ao manuscrito medieval, agora multiplicouse o número de obras e de exemplares, ademais de aumentar as posibilidades para acceder ao escrito de forma individual e, por iso, a Igrexa -máxime nun período como o da Reforma e a Contrarreforma-, a Administración e os movementos culturais -Humanismo, Barroco e Ilustración- servíronse da imprenta para difundir as súas ideas, valores e representacións da sociedade. Este fenómeno da difusión é a clave para interpretar o impacto da imprenta e, neste sentido, en Galicia tivo que afrontar non poucos atrancos: o analfabetismo, as dificultades de comunicación e transporte, a escaseza e precariedade técnica das imprentas, as dificultades económicas dos impresores, a mediocridade comercial ou a falta de especialización dos libreiros. Ademais, atopamos unha importante ausencia de editores e autores capaces de producir textos exportables e unhas bibliotecas institucionais e profesionais pobres e bastante anquilosadas na tradición ${ }^{18}$.

\footnotetext{
16 "Lectura y escritura en una ciudad del siglo XVI: Santiago de Compostela", En la España medieval, 6 (1985), páxs. 161-182 ou "Niveaux d'alphabétisation en Galice, 1635-1900", en De l'alphabétisation aux circuits du livre en Espagne, XVIe-XIXe, Paris, Éditions du CNRS, 1987, páxs. 45-71.

17 “Alfabetización y lectura en Asturias durante la Edad Moderna”, Espacio, Tiempo y Forma. Historia Moderna, 4 (1989), páxs. 115-134 ou "La lectura y sus problemas en el norte de la Península: estado de la cuestión”, Bulletin Hispanique, 99, 1 (1997), páxs. 75-97.

18 Ofelia Rey CAstelao, “A cultura escrita en Galicia. Séculos XVI-XVIII", en Pablo SÁncheZ FERro (dir.), Entre liñas: unha ollada á historia da cultura escrita en Galicia. Da Idade Antiga ao século XVIII, Vigo, Universidade de Vigo, 2006, páxs. 79-121.
} 


\section{Alfabetización FEMININA E ACCESO Á CULTURA ESCRITA}

No Antigo Réxime, a educación feminina pasaba máis pola instrución relixiosa e a aprendizaxe dos valores tradicionais cos que se definía o papel social das mulleres -piar fundamental da familia e do fogar-, que por adquirir as capacidades de ler e escribir. No caso feminino predominou o concepto de "educación" sobre o de "instrución", xa que este quedou reservado exclusivamente para a ensinanza masculina. De todos modos, cando se daban as circunstancias propicias, a lectura e a escritura, xunto cunha aritmética elemental, tamén constituíron os piares básicos da ensinanza ofrecida ás mulleres, sendo practicamente excepcionais os casos nos que se satisfacían outras inquietudes culturais, como os estudos de latín ou os universitarios.

Neste época, a lectura e a escritura eran saberes disociados, que se ensinaban separada e sucesivamente, mediante metodoloxías independentes entre si. Unha muller comezaba por desenvolver a súa capacidade lectora, sendo posible que non chegase a adquirir a destreza de escribir. Aprender a ler - primeiro o alfabeto, despois o silabeo e posteriormente frases e textos- era relativamente sinxelo e podíase facer de forma individual ou colectiva, sen grandes custes. Porén, escribir esixía moito máis tempo e recursos. Ademais, convén ter en conta que o dominio da escritura provocaba moitos máis receos porque, mentres resultaba bastante doado controlar o acceso das mulleres a unhas determinadas lecturas ${ }^{19}$, o dominio da escritura puña á súa disposición a posibilidade de desenvolver, crear e difundir un pensamento propio que, a meirande parte das veces, situaría ás mulleres ao borde da heterodoxia. Por exemplo, as mulleres poderían chegar a imitar comportamentos aprendidos nesas novelas cabaleirescas que a sociedade tanto insistía en prohibirlles, dando lugar ao intercambio de recados privados entre elas e os seus amantes.

Ao longo dos tres séculos estudados, estivo moi estendida a opinión de non ser imprescindible a ensinanza feminina. Partindo de nocións bioloxicistas, os tratados de educación da época consideraban que a muller era un ser débil en corpo e en espírito. Á inferioridade física corresponderíalle a intelectual e, aínda máis a moral, pola falta de razón, constancia e continencia. Daquela, ¿para que lles serviría ler e escribir ás mulleres? As campesiñas e labregas debían ocu-

\footnotetext{
19 Precisamente, durante o século XVIII, o tribunal da Inquisición abriu algunhas "causas de fe" referidas a cuestións relacionadas co libro e a literatura clandestina (impresión, venda, lectura, inspección de librerías e bibliotecas públicas e privadas, control nos portos dos libros que entraban no país e saían cara América, circulación, expurgo, confiscación, etc.). Vid. Martín GonZÁLEZ FERNÁNDEZ, El idioma de la razón. Ilustración e Inquisición en Galicia (1700-1808), Vigo, Nigratrea, 2008, páxs. 30, 180, 238-262. De todos modos, atendendo á documentación dispoñible, non parece que se exercera unha notable persecución contra as lecturas femininas ou contra as mulleres en tanto en canto produtoras, creadoras ou promotoras de libros prohibidos.
} 
parse da casa, a familia e a labranza, mentres as artesás axudarían nos negocios familiares sen que lles fora imprescindible ler e escribir. Incluso sen aprender formalmente unha aritmética elemental na escola, moitas mulleres chegarían a ser capaces de rexer os seus negocios sen dificultades. Ademais, no marco dunha sociedade analfabeta, a ensinanza veríase máis como un "plus" ca como unha auténtica necesidade ${ }^{20}$.

Non obstante, sen chegar a superar a indiferenza xeneralizada cara a ensinanza feminina -e tamén masculina-, os séculos modernos deron paso a unha serie de opinións favorables á educación de tódolos súbditos dos novos Estados Modernos e, en particular, á das mulleres ${ }^{21}$.

A pesar de que o Renacemento e o Humanismo non supuxeron o triunfo da Querela das mulleres -senón máis ben o seu fracaso-22, algunhas das súas figuras máis representativas, como Erasmo de Rotterdam e Luís Vives -autores presentes nas bibliotecas galegas-, afrontaron dun xeito favorable o problema da marxinación cultural das mulleres. Erasmo, por exemplo, defendeu a educación das nenas, pero só en nome do bo entendemento entre os dous membros da parella e sen romper cos roles tradicionalmente asignados ao sexo feminino. Na súa obra Sobre a instrución da muller cristiá, Luís Vives tamén concedeu primacía aos traballos domésticos e á formación moral sobre a lectura e a escritura. Porén, non dubidou en defender a educación feminina, afirmando que "a maior parte dos vicios das mulleres deste século e dos séculos anteriores ten a súa orixe na falta

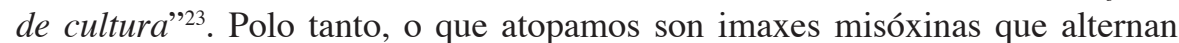
con outras de carácter positivo, para crear un arquetipo feminino definido pola obediencia e a submisión ao marido, o acatamento da norma moral, a castidade, $\mathrm{o}$ esforzo e o sacrificio en prol da familia. Ideal feminino similar ao que atopamos noutros autores do momento como Fray Antonio de Guevara, para quen as mulleres casadas debían ser maleables, resignadas, obedientes e pudorosas ${ }^{24}$.

Despois do Concilio de Trento, reafirmouse a necesidade de educar a tódolos fieis. Por iso, impulsouse o ensino dos adultos -a través da predicación e das

\footnotetext{
${ }^{20}$ Pegerto SAavedra Fernández, A vida cotiá en Galicia de 1550 a 1850, Santiago de Compostela, Universidade de Santiago de Compostela, 1992, páxs. 218-230.

${ }^{21}$ María José SÁnchez RodríGuez, La enseñanza de las letras en la educación de la mujer española (siglos XIII-XIX), Granada, Universidade de Granada, 2003, tese de doutoramento inédita, páxs. 73-212.

22 Joan Kelly, “¿Tuvieron las mujeres un Renacimiento?”, en James S. Amelang e Mary NaSH (eds.), Historia y género: las mujeres en la Europa moderna y contemporánea, Valencia, Edicions Alfons el Magnànim, 1990, páxs. 93-126.

${ }^{23}$ Martine Sonnet, "La educación de una joven", en Geoges Duby e Michelle Perrot, Historia de las mujeres. III. Del Renacimiento a la Edad Moderna, Madrid, Taurus, 2006, páxs. 143-144.

${ }^{24}$ M. J. SÁnchez Rodríguez, La enseñanza de las letras..., páxs. 83-91.
} 
misións no campo- e o dos nenos - por medio da catequese, que tendía a verse acompañada por uns rudimentos de alfabetización-. Neste sentido, as mulleres eran unha parte máis do conxunto da cristiandade e, ademais, no seu papel de nais, elas mesmas podían iniciar a (re)conquista moral e relixiosa da sociedade, de aí a súa importancia. Precisamente, a partir dese momento comezaron a xurdir unha serie de institucións relixiosas con intencionalidade educativa, como as Ursulinas, a Compañía de María ou as Fillas da Caridade. Porén, a educación que se lles ofrecía ás mulleres excluía os coñecementos relacionados coas linguas antigas, a retórica, a filosofía e, por suposto, todo o relativo á ciencia e á técnica ${ }^{25}$.

A pedagoxía da Igrexa queda perfectamente exposta por Frei Luis de León n'A perfecta casada, onde se defende ao fogar como o espazo de realización feminina por excelencia e a educación aparece definida pola adquisición duns rudimentos de lectura e escritura, o manexo do fío e da agulla e, sobre todo, polo coñecemento dunha relixión tinxida de moral. Pola contra, advirte que á muller "a natureza non a fixo para o estudo das ciencias, nin para os negocios de dificultades, senón para un só oficio simple e doméstico" ${ }^{26}$. Consecuentemente, a muller só podía aspirar a unha vivencia cultural repleta de libros devotos, biografías de santos e santas, novenas e pouco máis. Non obstante, a reiterada insistencia en que as mulleres se limitaran a ler obras de relixión deixando a literatura de ficción -especialmente as novelas cabaleirescas-confirma de forma indirecta que as poucas lectoras que había neste período lían algo máis que lecturas pías.

No século XVII, as posicións intelectuais relativas á educación feminina oscilaron entre a tradición ${ }^{27}$ e unha serie de opinións innovadoras, que reclamaban que os autores profanos, así como a historia e a poesía -con excepción daqueles textos contrarios á pureza de costumes-, debían estar presentes na educación das mulleres. Porén, estas novidades non chegaron a Galicia, onde uns mínimos rudimentos de lectura, escritura e cálculo, os labores de fío e agulla e, sobre todo, a instrución relixiosa seguirían sendo, con sorte, a máxima aspiración educativa das mulleres.

\footnotetext{
25 A. Costa Rico, Historia da educación..., páx. 319.

${ }^{26}$ Citado en Roberto J. LóPEz LóPEZ, "María como modelo de comportamiento para las mujeres según las publicaciones religiosas españolas del siglo XVIII", en David GonZÁLEZ CruZ (ed.), Vírgenes, reinas y santas. Modelos de mujer en el mundo hispano, Huelva, Universidad de Huelva, 2007, páx. 142.

27 Sería o caso de Claude Fleury no seu Traité sur le choix et le methode des Études (1685), que defendía como materias formativas a relixión, uns rudimentos de lectura e escritura e algo de aritmética práctica, de farmacopea, da ciencia do goberno da casa e de xurisprudencia. A. CosTA Rico, Historia da educación..., páx. 320.
} 
Durante o século XVIII volvemos a atopar esta dicotomía, xa que, aínda que se mantivo parte da realidade anterior ${ }^{28}$, o certo é que se foi incrementando o número de voces que manifestaban a súa crenza na capacidade intelectual das mulleres e, incluso, algunhas chegaron a postular a igualdade entre un e outro sexo ${ }^{29}$. Precisamente, algúns ilustrados galegos convertéronse en defensores dunha mellor educación feminina. Non obstante, cómpre salientar que o fixeron dende fóra de Galicia, xa que Madrid era o principal centro impresor da Monarquía e foi dende alí dende onde as súas obras conseguiron difundirse por toda a xeografía española.

Unha das figuras máis destacadas foi Frei Benito Feijoo, cuxo Discurso en defensa del talento de las mujeres y de su aptitud para el gobierno y otros cargos en que se emplean los hombres pretendía demostrar a invalidez de argumentos como o da suposta inferioridade natural das mulleres que lles impediría exercer diferentes roles sociais, especialmente, os de carácter público e científico, dos que tradicionalmente estaban -e continuaban, en gran medida- excluídas. Recorrendo á exposición de antecedentes históricos ${ }^{30}$, Feijoo apuntou aos factores históricos e culturais como causa da marxinación socio-cultural feminina. Por outra banda, o ourensán Vicente do Seixo publicou en 1801 o Discurso filosófico, económico y político sobre la capacidad o incapacidad natural de las mujeres para las ciencias y las artes. Nesta obra insistiu en atribuír as diferenzas sociais entre os dous sexos a que "non se lles dá a mesma educación". Porén, este autor entendía a educación nun sentido utilitario do máis tradicional, que non supuña ningunha alternativa para o desenvolvemento do sexo feminino: as mulleres deberían estar ben formadas, pero co obxectivo de educar mellor aos seus fillos.

Mais ¿que incidencia real tivo o pensamento ilustrado ${ }^{31}$ ? Barreiro Mallón sinalou como, en xeral, "as ideas máis ou menos innovadoras nacían, pero quedaban circunscritas aos membros de numerosos pero pequenos cenáculos, onde,

\footnotetext{
${ }^{28}$ Neste sentido resulta moi ilustrativo o pensamento de Rousseau, para quen a educación feminina só debería servir para o matrimonio e a maternidade, non para o desenvolvemento socio-intelectual das mulleres. M. SONNET, "La educación de una joven...”, páx. 152.

29 Entre este elenco de autores, tamén atopamos mulleres como Josefa Amar y Borbón co seu Discurso sobre la educación física y moral de las mujeres. Ma Victoria LóPEz-CORDón, Condición femenina y razón ilustrada: Josefa Amar y Borbón, Zaragoza, Universidad de Zaragoza, 2005.

${ }^{30}$ Este recurso xa contaba cunha longa tradición medieval. No que se refire ás mulleres e ás súas capacidades para desenvolver diversas actividades máis alá das tradicionalmente asignadas ao seu sexo, podemos destacar a súa utilización na obra de Cristina de Pizán, A cidade das mulleres, Santiago de Compostela, Xunta de Galicia, 2004.

31 Un espírito ilustrado que pode rastrexarse en disposicións como as do Regulamento de 1797, onde se engadiu nos plans de estudo das escolas de ensinanza de nenas a aprendizaxe da lectura, a escritura e a aritmética, xunto aos tradicionais coñecementos xerais de relixión e labores. Vid.
} 
ademais, tendían a deformarse" ${ }^{32}$. Así mesmo, Margarita Sanz indicou ao falar dos intentos reformistas dos ilustrados sobre a educación, que, aínda que na súa maioría non pasaron de proxectos teóricos ou de meros experimentos, "serviron para iluminar o problema, sentando as bases para o proxecto educativo, por primeira vez uniforme e centralizado, que cristalizou na segunda metade do século XIX"33.

Ao examinar os impresos galegos, comprobamos como estes están lonxe de inspirarse no ideario ilustrado ${ }^{34}$. Ademais, a finais do século XVIII, aínda unha das escolas particulares fundadas por don Benigno Rodríguez Araujo e Mon en Ribadeo só se centraba en ensinar ás rapazas a "ler, escribir, calcetar e coser e a mestra tiña que sacar ás nenas en procesión os sábados" 35.

Neste mesmo período foi cando a lexislación española comezou a establecer as bases para a creación dun sistema educativo estatal no que se incluirían ás mulleres $^{36}$. Pero, aínda que se chegou a sinalar que non se debían facer diferenzas entre nenos e nenas, o certo é que a propia actividade lexisladora impuxo que asistisen a escolas separadas dende 1771. Pese ao paternalismo dos ilustrados para coas mulleres, descóbrese no seu discurso unha clara limitación na ensinanza intelectual: procurábase promover a lectura, a escritura e un dominio básico de aritmética, pero dificilmente se atopan propostas para integrar ás mulleres no nivel das Escolas de Gramática ou nas Universidades.

No censo de Godoy de 1797 encontramos a primeira estatística oficial e xeral de escolas, onde aparecen un total de 561 escolas de primeiras letras para nenos, con 567 mestres e 14.533 alumnos, e 89 para nenas con 94 mestras e 1.699 alumnas. Cifras que constitúen un bo punto de partida para ver os significativos cambios que se descobren ao analizar os datos relativos á escolarización de mediados do século XIX (Gráfs. 1, 2, 3, 4 e 5) ) $^{37}$.

\footnotetext{
Alfredo MarTín García, Auge y decadencia: desarrollo económico, cultura y educación en Ferrolterra durante el Antiguo Régimen, A Coruña, Fundación Pedro Barrié de la Maza, 2008, páx. 240.

32 B. BARREIRo MALlón, "La lectura y sus problemas...”, páx. 77.

${ }_{33}^{3}$ M. SANZ GonZÁLEZ, "Alfabetización y escolarización...”, páx. 231.

${ }^{34}$ Así se desprende, por exemplo, da carta pastoral do arcebispo D. Francisco Alejandro Bocanegra y Xivaja, Declamación oportuna contra el libertinaje de el tiempo (Santiago de Compostela, Imprenta de Ignacio Aguayo, 1777), onde critica con espanto os novos tempos, antítese dos valores católicos.

35 O. Rey Castelao e S. Rial García, Historia das mulleres..., páx. 223.

36 José David Fernández Fraga, Lugo, siglo XVIII. Educación e Ilustración, Lugo, Deputación Provincial de Lugo, 1992, páx. 89.

${ }^{37}$ Realizadas en base aos datos aportados por O. Rey CAStelao, Libros e lectura..., páx. 61 e O. Rey Castelao, "Niveles de alfabetización...", páx. 296.
} 
Tendo en conta as ideas que acabamos de expoñer, podemos imaxinar facilmente as dificultades que tiveron que afrontar as mulleres para acceder á alfabetización. Non son moitos os datos dispoñibles, sobre todo para a Galicia da Alta Idade Moderna, porén, á hora de ver o punto de chegada, comprobamos como as mulleres capaces de ler per se os impresos galegos apenas chegaban ao $6,1 \%{ }^{38}$. Esta é a cifra de galegas que sabían ler ou ler e escribir en 1860, unha porcentaxe moi inferior á media española que era do 14\%. Pola contra, no caso dos varóns temos un 37,3\% para Galicia, fronte ao 35\% en España. Sen dúbida, as diferenzas entre sexos eran máis que notables (Gráf. 6$)^{39}$.

Con estas cifras, podemos falar dunhas altísimas taxas de analfabetismo feminino a finais da Idade Moderna, que se incrementarían canto máis nos retrotraeramos no tempo. E, ademais, a través delas podemos coñecer o número máximo de lectoras potenciais, aínda que non o de lectoras reais.

No Donativo de 1635 , só o 3,4\% das mulleres que aparecen -e fano en ausencia dos seus maridos- son capaces de asinar. Trátase de esposas de profesionais liberais ou de mulleres que recibían o tratamento de "dona", o que fai que a cifra sexa bastante superior ao menos do $1 \%$ que se observa no nivel de firmas das mulleres que ingresaban ou facían testamento no Hospital Real de Santiago ${ }^{40}$.

Un século máis tarde, a través da análise das compravendas de terra -nas que era moi frecuente a participación feminina-, comprobouse que no cuarto suroeste de Galicia asinaba entorno a unha décima parte das mulleres; porén, estes resultados deben ser analizados máis pormenorizadamente, pois a inclusión de zonas urbanas dá lugar a un incremento da porcentaxe de mulleres alfabetizadas $^{41}$. A través dos datos recollidos en Castroverde, no interior de Lugo, podemos apreciar a tendencia in crescendo destas taxas: mentres as mulleres non asinaban antes de 1700, na primeira metade do século XVIII fano o 1,7\%, na segunda, o $2,5 \%$ e, a comezos do século XIX, o $6,4 \%$.

\footnotetext{
38 Baixo esta cifra ocúltanse importantes diferenzas territoriais e socio-económicas. A meirande parte dos municipios non alcanzaban esa media, pero os núcleos urbanos, con taxas de alfabetización moito máis elevadas, facilitaron o incremento das cifras medias. Máis en detalle en O. REY Castelao, "Niveles de alfabetización...", páxs. 46-47.

39 Elaborada a partir dos datos ofrecidos por O. Rey CAStelao, "Niveles de alfabetización...", páx. 296.

40 O. Rey Castelao e S. Rial García, Historia das mulleres..., páxs. 218-219.

41 A pesar das diferenzas entre cidades, as taxas de alfabetización sempre foron superiores nos núcleos urbanos, onde vivía unha parte importante do clero, a cuarta parte de nobres e fidalgos e case tódolos comerciantes e profesionais liberais, funcionarios, administrativos e a meirande parte dos artesáns. O. Rey CASTElaO, “A cultura escrita...”, páxs. 92-93.

42 O. Rey Castelao e S. Rial García, Historia das mulleres..., páxs. 220.
} 
Vendo taxas tan modestas, cómpre preguntarse agora polos medios que se lle ofreceron ás mulleres para conseguir estes rudimentos da alfabetización, é dicir, ¿onde e quen lles ensinaba os rudimentos de lectura cos que terían un acceso directo á cultura letrada e particularmente aos textos impresos?

Ao longo de todo o período moderno, a asistencia á escola foi algo restrinxido a unha minoría de nenas. Algo similar acontecía cos nenos, aínda que, como xa vimos, as taxas de escolarización masculina sempre foron superiores ás femininas. A incorporación ao traballo en plena infancia puña en cuestión a utilidade última de aprender a ler e escribir. Ademais, a oralidade continuaba a ser o gran vehículo de transmisión cultural.

Se se cuestionaba a necesidade de educar aos nenos e nenas, é fácil de entender que o número de escolas para uns e para outras fose limitado. Á súa vez, a falta de escolas contribuía ao mantemento do analfabetismo, o que impediu unha relación máis activa e dinámica entre as mulleres e os produtos impresos. Mentres moitas nenas permaneceron afastadas da rede escolar, outras apenas chegaron a aprender algo nas non moi numerosas escolas mixtas, ás que os pais, que na maioría das veces eran os responsables de pagalas, adoitaban preferir enviar aos fillos antes que ás fillas, atendendo aos roles tradicionais para os que estarían destinados. Ademais, moitas destas escolas eran inestables e non funcionaron con toda a regularidade desexable. Os problemas para dotalas, a avaricia dos patróns e a irregular asistencia das nenas ás aulas contribuíron á existencia de fortes deficiencias no sistema de escolarización, especialmente, nos séculos XVI e XVII.

Ademais de ser poucas, parece que as escolas de nenas se limitaron ás cidades até o século XVIII, momento no que a situación económica e social trouxo consigo novas necesidades, como saber ler, escribir e contar, o que impulsou timidamente algunhas iniciativas educativas ${ }^{43}$. Pouco a pouco algúns clérigos, emigrantes, nobres ou membros das elites locais contribuíron a densificar a rede escolar coas súas fundacións. Así, a mediados do século XVIII, tódalas cidades e vilas galegas contaban con mestres de primeiras letras e, incluso, na cidade de Santiago de Compostela rexístranse catro mestras en 1753. Ademais de que a categoría profesional dos mestres carecía de recoñecemento oficial e dunha valoración positiva, a formación que se lles esixía ás mulleres que se querían dedicar á ensinanza, segundo a Real Cédula de 1783, consistía simplemente en doutrina cristiá e labores ${ }^{44}$. Novamente, parece que a lectura non era unha prioridade para a educación feminina.

\footnotetext{
${ }^{43}$ P. SaAVEdRa Fernández, A vida cotiá..., páx. 221.

${ }^{44}$ M. SANZ GonZÁLEZ, “Alfabetización y escolarización...”, páx. 245.
} 
Máis alá das escolas de primeiras letras mixtas ou especificamente para nenas, na Idade Moderna existían outros camiños polos que as mulleres puideron acceder a unha educación mínima. Na procura de cumprir ese "programa” educativo no que se insistía máis en aportarlle ás mulleres uns rudimentos da doutrina e unha mínima preparación para cumprir coas tarefas do fogar, a lectura e, sobre todo, a escritura podían quedar reducidas ao mínimo ou excluídas. A educación familiar procedía fundamentalmente das ensinanzas que as nais e as avoas transmitían ás nenas na procura de que conservaran as tradicións e saberes cotiáns e que se converteran en futuras esposas e nais, capaces de asumir os roles domésticos e tamén extra-domésticos asignados tradicionalmente ao seu sexo ${ }^{45}$.

Outras formas de acceso á educación por parte das mulleres foi a educación intrafamiliar non materna ${ }^{46}$ ou a contratación de preceptores no caso dunha minoría social. En Galicia temos constancia da ensinanza a cargo das tías, como no caso de María Antonia Pereira do Campo, e da existencia dunha mestra particular a mediados do XVIII que atendía ás fillas do fidalgo don Juan Antonio de Feijoo y Losada: dona María Magdalena Leal, de $18 \operatorname{anos}^{47}$.

No caso de nobres, fidalgas e burguesas foi moi frecuente que as nenas -as chamadas "educandas" 48 - fosen educadas por monxas en conventos e mosteiros na espera de saír para casar ou profesar nesas mesmas institucións, segundo o ditaminasen os intereses familiares. De todos modos, esa educación tampouco chegaría a superar, en gran medida, os niveis elementais: aprender doutrina cristiá, ler, escribir, facer contas e adquirir un verniz de bos modais e virtudes propias do sexo feminino. Convén destacar que estas rapazas desempeñaban unha importante función social á hora de reforzar as relacións entre os conventos e mosteiros nos que eran enclaustradas e as ricas e influentes familias das que proviñan. Tratábase dunha rede de relacións simbióticas de carácter socio-económico que conviña manter a ambas partes (Gráfs. 7 e 8$)^{49}$.

\footnotetext{
45 O. Rey Castelao e S. Rial García, Historia das mulleres..., páxs. 213-214.

46 Neste sentido foi fundamental a ensinanza a cargo dos tíos. En zonas como o interior lucense, a escaseza de escolas foi suplida pola abundancia de fillos "segundóns" nas casas, que aproveitaban os períodos invernais para estas tarefas. Ademais, tamén cobrou grande importancia a intervención dos numerosos eclesiásticos desocupados. O. Rey CAstelao, “A cultura escrita...”, páx. 92.

47 Olga Gallego Domínguez, Historia da muller. Mulleres ourensás dos séculos XIV-XVIII, Santiago de Compostela, Xunta de Galicia e Grupo Marcelo Macías, 2008, páx. 223.

48 Baudilio BARreiro Mallón, "Las educandas en clausura: convento o matrimonio", en Raquel Casal, Roberto J. López e José Miguel Andrade (coords.), Galicia monástica: estudos en lembranza da profesora María José Portela Silva, Santiago de Compostela, Universidade de Santiago de Compostela, 2009, páxs. 311-332.

49 Elaboradas a partir dos datos ofrecidos por O. Rey CASTElaO e S. Rial García, Historia de las mujeres..., páx. 255.
} 
En Santiago de Compostela atopamos outras iniciativas educativas como o “Colegio de Doncellas Huérfanas", fundado en 1596 polo arcebispo don Juan de Sanclemente e destinado a orfas dun certo nivel económico, onde lles ensinaban doutrina cristiá e outros "labores da casa" ${ }^{50}$. Na segunda metade do século XVIII fundouse o colexio da Compañía de María ou da Ensinanza destinado á escolarización de nenas ${ }^{51}$. O centro organizouse entorno a dous niveis educativos. $\mathrm{O}$ nivel superior levaba consigo a entrada no internado cara os seis ou sete anos. Tratábase fundamentalmente de nenas das clases medias e da nobreza que vivían sometidas a unha ríxida disciplina e cuxa educación consistía, fundamentalmente, en "doutrina e normas de comportamento, e os coñecementos ou a cultura non pasaban dun grao moi elemental" 52 . No segundo nivel, atopámonos con nenas de escola primaria cuxo ensino era gratuíto e xeral. A Compañía de María tiña o seu propio modelo para a actividade docente, consistente, tal e como se reflicte nas constitucións publicadas en Zaragoza no ano de 1745, en catro horas diarias nas que as nenas asistirían ás aulas de modo separado en grupos de ler, escribir e coser; ensinándose na primeira a "ler latín, despois romance e letra de man, a pracer e tirada, bastarda y de notario" e todo indica que se facía seguindo a cartilla ${ }^{53}$.

En Ourense, o bispo don Diego de Zúñiga fundou en 1632 o "Colexio das Mercedes", no que as mozas eran educadas na virtude e nos labores propios do seu sexo, como indican as Constitución dadas polo bispo Frei Baltasar de los Reyes $^{54}$. Na segunda metade do século XVI, o ensino da doutrina cristiá tamén era a clave na educación que se ofrecía ás nenas nobres que residían no convento vigués dos Remedios do Areal, que fora fundado un pouco antes por dona Inés Pérez de Çeta $^{55}$. No caso de Betanzos existiu un colexio para orfas, dedicado a

\footnotetext{
${ }^{50}$ O. Rey Castelao e S. Rial García, Historia das mulleres..., páx. 233. Neste colexio empregábase polo menos unha hora pola mañá para clases de lectura. Ademais, debían practicar esta destreza xa que, como se indica nas Constitución outorgadas polo arcebispo don Pedro Carrillo y Acuña en 1663, cara o mediodía "la doncella que fuere de semana subirá al púlpito a leer algún libro espiritual, o vidas de santos según las festividades (...)", o que debía repetir media hora antes das tres. Vid. José Manuel Domínguez García, Cátedras de gramática y educación en Galicia, siglos XVI y XVII, A Coruña, Fundación Pedro Barrié de la Maza, 2010, páx. 67.

51 O. Rey Castelao e S. Rial García, Historia das mulleres..., páxs. 234-237. A fundadora da Compañía de María foi Xoana de Lestonnac (1556-1640), educada nun ambiente refinado e humanista. A súa finalidade era instruír ás mozas na virtude, a piedade e a doutrina cristiá, para o que asumiu e adaptou a filosofía pedagóxica e didáctica da Ratio Studiorum xesuíta. A. Costa Rico, Historia da educación..., páxs. 320-322.

52 O. Rey Castelao e S. Rial García, Historia das mulleres..., páx. 237.

53 O. Rey Castelao e S. Rial García, Historia das mulleres..., páx. 237.

54 O. Gallego Domínguez, Historia da muller..., páx. 223.

55 A. Costa Rico, Historia da educación..., páx. 546.
} 
san Nicolás, fundado en 1631 por Úrsula Meléndez de Tejada, destinado a soster e educar doce mozas orfas ${ }^{56}$. En Ferrol, para a segunda metade do século XVIII, aínda son moi escasos os testemuños sobre a existencia de escolas para nenas ${ }^{57}$.

Tras recibir esta formación rudimentaria de primeiras letras, aos nenos -a unha minoría, por suposto- ofrecíaselles a oportunidade de seguir formándose a través das cátedras de gramática consagradas, fundamentalmente, ao estudo do latín. Para as nenas esta ensinanza "secundaria" e maila universitaria non eran tidas en conta, aínda que tampouco podemos falar de prohibicións absolutas como demostran os casos de dona Francisca de Lebrija, que desempeñou unha cátedra na Universidade de Alcalá, dona Álvara de Alba, que figura matriculada en Salamanca en 1546 e dona Feliciana Enríquez de Guzmán, que segundo Lope de Vega, estudara en Salamanca disfrazada de home ${ }^{58}$. Pese a este distanciamento entre as mulleres e os niveis de ensinanza medios e superiores, cómpre sinalar que moitas fundacións debéronse a iniciativas femininas, o que demostra a importancia concedida á educación, aínda que se manifestara a través do mantemento de prexuízos de xénero, profundamente arraigados nas mentalidades (masculinas e femininas) do momento ${ }^{59}$.

\footnotetext{
56 J. M. Domínguez García, Cátedras de gramática..., páx. 248. Esta protección cara as orfas tamén deu lugar a outras fundacións como a de dona Juana Díez de Lemos, mediante a cal dotou a seis orfas para favorecer o seu acceso ao matrimonio ou ao convento.

57 E unha das escasas referencias que hai é a dunha mestra, Juliana Ate, que tiña unha escola en Esteiro, onde ensinaba ás nenas a "ler e escribir, calcetar e coser". A. MarTín García, Auge y decadencia..., páxs. 240-242.
}

${ }^{58}$ M. J. SÁnchez Rodríguez, La enseñanza de las letras..., páxs. 69-70.

${ }^{59}$ Sen pretender sermos exhaustivos, convén sinalar algúns exemplos deste activo papel das mulleres á hora de crear centros educativos -aínda que moitas veces só foran destinados aos varóns-. En 1563, dona María Sarmiento de Ribadeneira, viúva de Gómez Pérez das Mariñas creou o Colexio da Natividade en Viveiro destinado a estudantes de gramática e teoloxía moral. En 1593, dona Ana Álvarez de Montaos ampliou o estudo de gramática de Pontevedra fundado unhas décadas antes. En 1694 ou 1695, dona Margarita Pardo de Cela y Montenegro fundou a cátedra pública de Artes no convento dos dominicos de Viveiro e tamén unha escola para nenos. Mediante o seu testamento, outorgado en 1587, a muller do capitán e fidalgo Juan Losada, Marina Pérez, fundou unha obra pía para dotar dúas bolsas de estudo de bacharelato en Salamanca ou no colexio xesuíta de Monterrei e Beatriz Novoa Sandoval fundou en 1633 outra con 1.000 ducados para un parente estudante de "ciencia" nunha universidade. Dona Catalina de la Cerda, condesa de Lemos, legou 100 ducados ao colexio de xesuítas do que a súa familia fora mecenas e 200 ao convento dos franciscanos para que mantivesen os estudos de artes; ademais, en 1648 dotou con 5.000 ducados de renda unha cátedra de teoloxía dogmática no convento dominico de San Xacinto. En 1782, a Condesa de Torrejón el Rubio, viúva do IV Marqués de Vilagarcía outorgou unha doazón á escola de ler e escribir de Vilagarcía e para dotar a doncelas orfas. Por outra parte, as mulleres tamén chegaron a exercer o padroádego, como se documenta para as cátedras de Betanzos e Melide. Na segunda metade do XVI, dona Inés de Velasco, muller do Conde de Monterrei, tentara proseguir, sen éxito, coa tentativa de seu marido de converter o colexio de xesuítas dese lugar en Universidade ou Estudo Xeral. Vid. J. 
No caso galego, estamos falando, ademais, dunha alfabetización en castelán, lingua allea á meirande parte da sociedade, que sería galegofalante, pero que monopolizaba as producións impresa e manuscrita. Daquela, cabería preguntarse se as mulleres e os homes que só accederon aos rudimentos da escritura realmente serían capaces de expresárense nesa lingua por escrito. Moi posiblemente, a cuestión lingüística tamén dificultou o desenvolvemento formativo e cultural das galegas da Galicia moderna.

Como puidemos comprobar, as taxas de alfabetización feminina foron moi baixas na Galicia do Antigo Réxime: nos grupos populares, o analfabetismo foi unha realidade xeneralizada e, entre as mulleres mellor situadas socialmente, a formación non deixou de ser limitada e accesoria. Así, a pesar da diversidade de opcións que se ofrecen para a aprendizaxe (a escola, a familia, os preceptores, os conventos, etc.), non podemos falar de intensas relacións entre mulleres e cultura letrada, o que, sen dúbida, condicionou e determinou a relación entre o sector feminino e os produtos da imprenta.

Pero, en relación coas mulleres alfabetizadas, ¿podemos chegar a coñecer os seus hábitos de lectura? Non parece doado e algúns dos traballos realizados até o momento non acaban de resultarnos plenamente satisfactorios.

Unhas das fontes máis empregadas para tentar coñecer este acceso das mulleres á posesión do libro e, por extensión, á lectura foron os inventarios post-mortem. Porén, son moitas as dúbidas que nos suscita esta fonte ao inventariárense libros ou bibliotecas cuxa orixe e propiedade non quedan claras. Na meirande parte dos casos, particularmente cando se trata de viúvas, as bibliotecas particulares atribuídas a elas ben puideron pertencer aos maridos ou a calquera outro home da familia. Cómpre ter en conta tamén que estas bibliotecas puideron xurdir como resultado dun proceso de sedimentación no que se acumularían obras procedentes de diversas herdanzas, compras, agasallos, etc.

Na Galicia moderna a posesión do libro foi moi reducida. Dende unha perspectiva social, limitábase aos clérigos, fidalgos e campesiños ricos, fundamentalmente. Pero, ademais de teren poucos libros, estes adoitan ser de contido relixioso: manuais de devoción, oracións e vidas de santos. Sen dúbida, temáticas que non facían máis que consolidar a ortodoxia católica e, consecuentemente, gran parte do imaxinario feminino que xa se fora configurando ao longo do período medieval.

O que está claro é que a distribución social e territorial do libro estivo condicionada polo nivel de renda, a categoría socioprofesional, a zona de residencia e, tamén, polo sexo dos propietarios.

M. Domínguez García, Cátedras de gramática... e O. Rey Castelao e S. Rial García, Historia das mulleres..., páx. 224. 
Dende o século XVI foise rexistrando progresivamente unha maior presenza de libros entre os grupos urbanos, especialmente entre os clérigos e os sectores profesionais (avogados, xuristas, médicos, mercadores, algúns artesáns, etc.). Por iso, non resulta sorprendente que a meirande parte das obras rexistradas en inventarios fosen libros de oficio ou de relixión. No século XVIII, prodúcense pequenos cambios en canto á diversidade temática rexistrada, o que favoreceu, moi posiblemente, o acceso das mulleres aos libros. Entre a nobreza e a fidalguía compostelá atopamos un trinta por cento de títulos de historia, outro tanto de relixión e algúns de literatura, todos eles libros que poderían satisfacer o interese lector das mulleres -non tanto os libros de ciencias, dereito ou outros temas que esixían certa formación-. Similares contidos atopamos entre o sector burgués, onde destaca o catorce por cento correspondente a obras de literatura, sobre todo, do Século de Ouro ${ }^{60}$.

Respecto á nobreza galega, esta tendeu a residir fóra do vello Reino na procura de consolidar a súa posición social, política e económica, situándose arredor da Corte. Por iso, non nos imos deter nas súas coleccións de libros. Só traeremos aquí un exemplo que ilustra ben como os inventarios das bibliotecas deben ser analizados con precaución. No tránsito do século XV ao XVI, o nobre castelán don Enrique Enríquez casou con dona Francisca Sarmiento, herdeira do morgado que acababa de fundar o conde de Ribadavia, don Bernardino Pérez Sarmiento. Cando se fixo o inventario da súa biblioteca, publicado por Olga Gallego, atopamos arredor de 83 obras, entre as que aparecen indicios de que a biblioteca, presentada baixo a titularidade de don Enrique, puido ser unha biblioteca compartida ou, cando menos, formada con aportes de ambos cónxuxes. Entre outros libros aparece citado un que estaba encadernado en azul coas armas dos Sarmiento, a liñaxe da esposa, e outros escritos en galego e portugués, que, moi probabelmente, tería levado a Condesa dende Galicia a Castela ${ }^{61}$. Non hai datos sobre a lectura en si mesma, pero si se fai evidente que non é fácil discernir entre cales serían "bibliotecas femininas" propiamente ditas e cales masculinas.

Queremos insistir, pois, en que non se pode establecer unha relación de equivalencia entre a posesión de libros e a súa lectura e que a titularidade feminina de bibliotecas ou de pequenos conxuntos de libros non implicaba que as mulleres procedesen á súa lectura.

60 O. Rey Castelao e S. Rial García, Historia das mulleres..., páxs. 240-241.

${ }^{61}$ Miguel García-FernándeZ, "Las Sarmiento: mujeres con poder al final de la Edad Media", en $\mathrm{M}^{\mathrm{a}}$ Isabel del VAL VALdivieso e Cristina Segura Graíño (eds.), La participación de las mujeres en lo político. Mediación, representación y toma de decisiones, Madrid, A. C. Almudayna, 2011, páx. 142. 
Agora ben, de aceptar a existencia de "bibliotecas femininas" ¿cales poderían ser os trazos que as caracterizarían? Máis alá da falta de profesionalización -que parece evidente por motivos obvios-e do peso da relixión -habitual tamén no caso dos homes-, non hai máis que unha serie de indicios e de datos cualitativos que impiden extraer conclusións definitivas ${ }^{62}$.

Cátedra e Rojo sinalan como entre os copistas, libreiros e autores da época parece perfilarse unha categoría que, baixo o nome de "libros de mujer", alude a un tipo de libro concreto:

\begin{abstract}
“normalmente pequeno, sempre en lingua romance, con contidos pouco variados, que inclúen os libros de oracións, os libros relixiosos e de espiritualidade sensible e independente, aínda que tamén unha certa ficción literaria, e manuais especializados en variedades ou misceláneas "63.
\end{abstract}

É certo que dun xeito ou doutro, pode que a través de lecturas en voz alta, a presenza de libros acabaría repercutindo beneficiosamente na formación cultural feminina. Así acontecería, por exemplo, coas nais, irmás, criadas e, talvez tamén, coas mancebas de clérigos que convivían con estes. Os sínodos diocesanos animaban aos relixiosos a que lesen en voz alta algunha lectura piadosa para que a escoitaran as súas familias. Dato moi interesante, que revela a utilización da lectura como vía de adoutrinamento por parte da ortodoxia cristiá católica. Algo similar lle aconteceu a María Antonia Pereira, fundadora das carmelitas compostelás, que relata como mentres ela e outras compañeiras tecían na casa da súa tía, unha lía diversos textos como vidas de santas ou textos de Santa Teresa de Jesús.

Máis alá dos libros de posesión persoal ou familiar, hai indicios de que a comunidade lectora tivo acceso á cultura letrada por outras vías, por exemplo, a través do préstamo bibliotecario e, moi posiblemente, dos préstamos entre amigos, coñecidos e parentes; realidades que non resultan fáciles de documentar.

No caso das relixiosas galegas, sorprende que non se documentaran bibliotecas nos seus conventos e mosteiros, sobre todo, porque para profesar si se lles esixía saber ler e escribir e, no caso das dominicas de Belvís, aprender latín ${ }^{64}$.

\footnotetext{
62 Ángel Weruaga Prieto, Lectores y bibliotecas en la Salamanca moderna. 1600-1789, Salamanca, Junta de Castilla y León, 2008, páxs. 231-249 e Pedro M. Cátedra e Anastasio Rojo, Bibliotecas y lecturas de mujeres. Siglo XVI, Salamanca, Instituto de Historia del Libro y de la Lectura, 2004, páxs. 87-88. Estes dous últimos autores confían nos inventarios post-mortem como fonte básica para o tema, o que deixa fóra a lectura de obras diferentes ás posuídas, ademais de asumir, dun xeito un tanto atrevido, que se le o que se posúe.

63 P. M. CÁtedra e A. Rojo, Bibliotecas y lecturas..., páxs. 87-88. A tradución é nosa.

64 Weruaga descubriu algo similar ao estudar as "lecturas de xénero" na Salamanca dos séculos XVII e XVIII. Tamén alí os títulos dos que se dispuña dentro do claustro non eran demasiados e
} 
Dende a clausura, a existencia destas bibliotecas institucionais posibilitaríalles incrementar a súa formación e ampliar a listaxe de lecturas que, doutra forma, quedarían reducidas ás obras de pertenza individual que tiveran nas súas cel$\operatorname{das}^{65}$.

Finalmente, ¿que podemos dicir sobre as bibliotecas particulares das galegas? Pouco e sen novidades polo momento. As dúbidas sobre se eran ou non delas os libros que figuran nos seus inventarios e se chegaron a lelos persisten. Faremos referencia, pois, a un único caso, o de dona Ana de Toledo, condesa de Altamira, de quen conservamos un inventario de bens, datado en 1549. Para M ${ }^{\mathrm{a}}$ Carmen Pallares, este documento supón un motivo de optimismo á hora de valorar o nivel cultural das mulleres do momento, pois:

"non só se mencionan xa libros que teñen que ver coa vida espiritual-li-
bros de horas, abecedarios espirituais, libros de ben morrer-, senón tamén
libros de poesías -un de Ausias March, entre eles-, libros de cociña-dous
que se refiren ás conservas de alimentos-e outro de medicamentos"

Leunos? Aínda que polos temas parece moi probable que así fora, lamentablemente, nunca poderemos ter a total e absoluta certeza.

Máis alá da alfabetización das mulleres ou das dificultades existentes para analizar a posesión de libros, os hábitos lectores e os contidos das lecturas femininas, a relación das mulleres coa cultura letrada e coa produción impresa en particular remítenos a outras cuestións como a autoría e o traballo feminino no mundo da imprenta.

a súa posesión estaba moito máis regulada ca no mundo exterior. Á. WeruAGa PrIETO, Lectores y bibliotecas..., páx. 248.

${ }^{65} \mathrm{O}$ certo é que os nosos coñecementos seguen sendo moi limitados neste ámbito. Por iso, podemos lembrar as conclusións ás que chegou Clara Rodríguez Núñez na súa tese sobre os conventos femininos baixomedievais: "se ben os conventos de relixiosas mendicantes non parecen desempeñar en absoluto un papel cultural semellante ao dos freires, permiten ás mulleres que neles ingresan acceder a unha certa educación. Que esta se reducira á lectura e o canto, deixando probablemente de lado a escritura, e que esas lecturas fosen esencialmente de tipo relixioso non debe impedirnos valorar na súa xusta medida esta vía educacional feminina. (...) Pese a tódalas súas limitacións, as monxas atópanse, tamén no aspecto cultural, nun nivel superior ao das laicas do seu mesmo entorno social". Clara Cristela Rodríguez NúñEz, Los conventos femeninos en Galicia: el papel de la mujer en la sociedad medieval, Lugo, Deputación Provincial de Lugo, 1993, páx. 160.

${ }^{66} \mathrm{M}^{\mathrm{a}}$ Carmen Pallares Méndez, Historia das mulleres en Galicia. Idade Media, Santiago de Compostela, Nigratrea, 2011, páx. 253. Para unha identificación das obras do inventario de dona Ana, vid. Pedro M. CÁtedRa e Anastasio Rojo, Bibliotecas y lecturas..., páxs. 403-405. 


\section{AS MULLERES E A PRODUCIÓN IMPRESA: AUTORAS E PRODUTORAS}

Se o acceso das mulleres á produción impresa estivo condicionada polas taxas de alfabetización feminina, non cabe dúbida de que outro factor decisivo é o que se refire á propia produción e materialización dos impresos. Para lelos, era preciso ser quen de facelo, máis tamén contar con eles, fosen libros ou calquera outro tipo de impreso, independentemente das súas dimensións e calidade literaria. Neste segunda parte procuraremos achegármonos brevemente á actividade das mulleres no mundo da imprenta galega durante os séculos XVI, XVII e XVIII para coñecer mellor o seu papel como produtoras, vendedoras, creadoras e, incluso, promotoras de impresos ${ }^{67}$.

Xa antes da invención da imprenta, as mulleres medievais -fundamentalmente relixiosas- contribuíron á produción e decoración de manuscritos. Por iso non é de todo estraño que, cando se consolidou a actividade impresora en pequenos negocios familiares propiedade dun mestre impresor, tamén atopemos neles ás mulleres, especialmente cando a viuvez ou a ausencia de irmáns varóns lles ofreceu a posibilidade de acceder á xefatura da imprenta. Porén, parece inexistente a figura da impresora que, por decisión propia, se encargara dun taller. Ademais, non resulta fácil determinar que actividades concretas realizarían nestes talleres. A pesar de todo, o certo é que, na maioría dos centros impresores da Península, podemos atopar mulleres imprimindo co seu nome ou baixo a fórmula de "Viúva de". En numerosas ocasións, as viúvas ou as fillas de impresores acabaron casando con colegas dos seus maridos finados ou dos seus pais, o que as converteu en pezas fundamentais para a transmisión de talleres impresores, dando continuidade á tradición familiar ${ }^{68}$.

Na Compostela do século XVI, atopamos a Beatriz López Pacheco, viúva de Agustín de Paz, imprimindo en 1562 a obra de Francisco de Vitoria, Confesionario útil y provechoso. Esta impresora deu continuidade ao negocio grazas á axuda do libreiro Alonso de Cárdenas, aínda que, xa en 1588, cedeu as prensas ao seu fillo. Neste mesmo século, María López, filla do impresor Nicolás Thierry, casou co libreiro Andrés Pajazo, o que contribuíu a consolidar a imprenta en Compostela.

\footnotetext{
${ }^{67}$ Ao longo do traballo diferenciaremos entre produtoras e creadoras/autoras. Mentres co primeiro termo designamos ás mulleres que participaron de forma directa ou indirecta nas tarefas da impresión, é dicir, que axudaron á producir fisicamente o impreso, coa denominación de "creadoras" referirémonos á autoría feminina.

68 Manuel José Pedraza-Gracia, "Las mujeres en la imprenta hispana durante los siglos XV y XVI", en Concepción García Caro e Josefina Vílchez Pardo (coords.), Estudios de documentación dedicados a su memoria. Homenaje a Isabel de Torres Ramírez, Granada, Universidad de Granada, 2009, páxs. 587-605.
} 
Dende finais do XVII, as mulleres xogaron un papel fundamental na consolidación e transmisión do taller impresor dos Fraiz. Esta casa impresora, unha das máis importantes de Compostela -o que, nestes momentos, equivalía a dicir de toda Galicia-, xurdiu a partir do casamento do fundador, Antonio Fraiz, con Petronila López de Goldar, cuñada do impresor José do Canto -cuxa estancia en Compostela foi breve, de 1660 a 1668-. Esta mesma imprenta dos Fraiz pasou por algunhas dificultades que logrou superar grazas a unhas acertadas políticas matrimoniais de carácter endogámico. A imprenta de Antonio Pedache, ante a ausencia de fillos varóns, foi herdada en 1714 polo marido da súa filla Cayetana Antonia, Andrés Fraiz. Posteriormente, outra muller, neste caso Cayetana Andrea Fraiz, sucedeu ao seu marido Sebastián Montero Fraiz, quen asumira nun primeiro momento a dirección do taller impresor dos Fraiz, que, non obstante, lle pertencería por herdanza a Andrea, filla de don Andrés ${ }^{69}$. De todos modos, parece que esta muller pronto cedeu a xestión da imprenta ao seu sobriño D. Francisco Montero, "xa que dona Andrea dificilmente podía facerse cargo da mesma por ser analfabeta", segundo nos di Odriozola.

O outro gran taller impresor da Galicia do XVIII, o dos Aguayo, tamén contou con significativas presenzas femininas. De feito, o matrimonio entre Antonia Jacinta, unha filla do impresor Antonio de Aldemunde, co oficial deste, Ventura Aguayo, inaugurou este taller, un dos máis prolíficos do momento. Ignacio Aguayo, impresor de dilatada carreira, foi sucedido, xa en 1819, pola súa filla segunda e o seu xenro. O feito é que este taller gozou dunha posición desafogada á que tamén contribuíron mulleres como María Ventura Vázquez Salinas, viúva do pintor Andrés Barreiro e primeira muller de Ignacio Aguayo. A este casamento María aportou non só mobles, cadros e xoias, senón tamén 8.000 reais.

Sen dúbida, as mulleres e as familias dos impresores, en contacto diario coa cultura e as instancias que a promovían e consumían, gozaron dunha alta estima e respectabilidade social, o que iría parello a un relativo equilibrio do nivel económico $^{70}$.

Máis alá do taller impresor, a relación entre as mulleres e os produtos da imprenta deuse nas librerías. Na cidade de Ourense, Olga Gallego documentou a presenza da libreira Ana Sánchez ${ }^{71}$. Como nos recorda esta autora, os libreiros tentaron especializarse tamén na encadernación e na comercialización de libros,

\footnotetext{
69 Sobre a evolución e prácticas sucesorias da imprenta Fraiz no século XVIII, vid. Yolanda BARRIOCANAl LóPEZ, El gravado compostelano del siglo XVIII, A Coruña, Fundación Pedro Barrié de la Maza, 1996, páxs. 23-26.

70 Y. Barriocanal López, El gravado compostelano..., páxs. 27-35.

71 O. Gallego Domínguez, Historia da muller..., páxs. 189-197.
} 
competindo cos mercadores. Ademais, podería darse o caso de que algúns imprimiran algo sen acudir ás imprentas compostelás, as únicas existentes na Galicia dos séculos XVII e XVIII, ou a outras alleas ao vello Reino. Filla do libreiro Alonso Sánchez e de Francisca Ramos, Ana Sánchez tivo unha irmá, chamada María, que casou en 1592 co ensamblador Pedro Brunes, natural de Flandes. Na carta de dote desta última, establecíase que os cónxuxes vivirían un ano cos pais dela, baixo a condición de que o que María gañase durante ese ano no oficio e arte de libreiro, ou en calquera outro, fose para os seus pais. Compróbase, así, como no ámbito libreiro, tal e como acontecía en moitos outros, contábase cunha importante axuda intrafamiliar feminina, que favorecía un primeiro contacto entre as mulleres e a produción impresa.

Máis activo debeu ser o papel da propia Ana Sánchez ao casar cun colega de seu pai, o libreiro Domingo Gómez, tal e como era habitual entre os artesáns e mercadores. En 1609, cando outorgou o seu segundo testamento, Ana xa estaba viúva, mais continuaba co negocio familiar. Non sería até o 23 de agosto do ano seguinte, o mesmo día no que testou por terceira e derradeira vez, cando Ana Sánchez morreu. No reconto dos seus bens e da librería rexistráronse 195 obras que nos permiten retratar o gusto da clientela ourensá: obras relixiosas como misais, breviarios ou vidas de santos, obras de autores clásicos como Aristóteles, Virxilio, Cicerón, Tito Livio, Ovidio, Xuvenal e Esopo, de autores contemporáneos como Frei Luís de Granada ou libros de xurisprudencia, de cirurxía e de ensinar a ler e escribir. Ao mesmo tempo, tamén deixou gravados en madeira, estampas, impresos de poderes, "paulinas" e cartas de pago, así como papel en branco e tres peles de pergamiño e instrumentos do oficio de encadernador.

Tamén en Compostela as mulleres rexentaron librerías herdadas dos seus maridos. É o caso da xa citada viúva de Agustín de Paz ou da viúva de Alonso Díaz. A mediados do século XVIII documéntase a unha dona Josefa María Díaz como mercadora de libros, gañando 2.400 reais anuais, cifra importante se a comparamos cos ingresos doutras mulleres profesionais ${ }^{72}$.

Finalmente, non podemos esquecer que houbo outras mulleres, das que non temos constancia sobre unha participación activa nas librerías, pero que si contribuíron á conformación dunha densa rede de relacións entre impresores e libreiros. Na Compostela da primeira metade do XVI, a filla do impresor Thierry, María López, casou con Andrés Pajazo, libreiro de Santiago, quen, en 1541, dotou á súa criada Juana Fernández -que antes o fora de N. Thierry-, para o seu casamento con outro libreiro da cidade, Gerardo del Sol, quen compraba libros

${ }^{72}$ O. Rey Castelao e S. Rial García, Historia das mulleres..., páxs. 102-103. 
procedentes de Francia e de Flandes e de cuxa librería se conservou un nutrido inventario $^{73}$.

Se ben é certo que podemos rastrexar facilmente a presenza feminina na produción e comercialización de produtos impresos, sobre todo grazas ao seu papel como viúvas e herdeiras, máis dificultades atopamos á hora de caracterizar ás mulleres como creadoras intelectuais dos mesmos. Non obstante, pese a ser negada ou cuestionada a autoría feminina en numerosas ocasións, ao longo do período moderno apareceron diversas mulleres capaces de dar o salto da lectura á escritura. Non deixaron de ser unha minoría letrada -o mesmo que acontecía cos homes- xa que, ademais das dificultades propias do momento para acceder a unha alfabetización mínima, tiveron que afrontar os prexuízos de xénero que as consideraban intelectualmente inferiores aos homes. Nomes como María de Zayas ou Santa Teresa de Jesús responden a estas mulleres excepcionais, pero reais ao fin e ao cabo. No caso galego, condicionado polo seu carácter periférico, con mínimas taxas de alfabetización e cunha alta nobreza afastada do vello Reino, agrávanse as ausencias femininas na autoría da cultura letrada. Poden acceder a ela, aínda que non poidamos determinar con claridade en que medida, como, cando, onde ou para que. Pero ¿crear? Non semella tan doado e, de facelo, ¿chegaron os seus manuscritos á imprenta? ¿En que imprentas publicaron as súas obras as galegas?

Resulta lóxico e evidente que, nunha aproximación prosopográfica, atopemos ás autoras galegas da Época Moderna entre os grupos sociais privilexiados. Nunha sociedade como a do Antigo Réxime na que o acceso á cultura letrada estaba determinada por circunstancias como a da pertenza a un determinado grupo social, tamén actuaron como condicionantes outros factores como os apuntados por dúas autoras tan destacadas como Cristina de Pizán ou Virginia Woolf: a necesidade dun espazo propio e a dispoñibilidade de tempo para escribir. Todo isto determina que sexa entre a nobreza e unha pequena elite de relixiosas, onde teñamos que buscar, fundamentalmente, ás mulleres creadoras.

Dona Isabel de Castro y Andrade (1510-1582) é unha das poucas poetisas galegas das que temos constancia para o período estudado. Filla do IV Conde de Lemos, dona Isabel foi condesa de Altamira tralo seu casamento con don Rodrigo Osorio de Moscoso. Pese ao pouco que se coñece da súa obra, é reivindicada como a primeira escritora galega coñecida, grazas á conservación dun soneto escrito en galego, publicado na honra de Alonso de Ercilla, nunha edición impresa

\footnotetext{
73 Antonio Odriozola e Xosé Ramón Barreiro Fernández, Historia de la imprenta en Galicia, A Coruña, Biblioteca Gallega, 1992, páx. 136. O "requento e inventario que yo Juana [Fernández] (...) fynqué de Giraldo del Sol librero" foi publicado en Benito Rial Costas, Producción y comercio del libro en Santiago (1501-1553), Madrid, Calambur, 2007, páxs. 209-274.
} 
en Madrid de La Araucana. Como vemos a través deste caso, a autoría feminina dáse na máis alta xerarquía social e, a pesar de que este poema chegou á imprenta, fíxoo lonxe de Galicia onde, en 1589, a literatura contemporánea apenas tiña cabida nas pequenas imprentas aquí situadas ${ }^{74}$.

Se este é o panorama que atopamos a comezos do período moderno, ¿que sucede no século XVIII, o Século das Luces e da Razón? Neste contexto de continuos debates sobre a capacidade intelectual das mulleres e o seu dereito a acceder a unha mellor educación, as cousas non parece que mudaran moito.

María Antonia Pereira do Campo (1700-1760), máis coñecida como a monxiña do Penedo, foi a fundadora das Carmelitas en Santiago de Compostela. Esta muller legou á posteridade unha importante produción escrita que abarca a súa Autobiografía, redactada en dous períodos entre 1737 e 1755, un texto místico titulado Edificio Espiritual, que nunca chegou a publicarse, e un amplo epistolario composto por 331 cartas, dirixidas non só a homes -confesores, prelados, sacerdotes e cabaleiros-, senón tamén a mulleres e, moi especialmente, á súa filla, tamén relixiosa. Trátase dunha produción ampla que, a diferenza do que aconteceu cos escritos doutras relixiosas do momento, non pasou á imprenta. Analizada dende a perspectiva de xénero e da historia cultural, a obra de María Antonia Pereira permítenos aprehender algo máis sobre a cultura feminina na Galicia moderna a través da súa propia experiencia.

Como gran parte das mulleres do seu tempo, María Antonia non foi escolarizada e viviu nun mundo no que a fala cotiá e, consecuentemente, a cultura oral estaban expresadas en lingua galega. Porén, a imposibilidade de acceder a unha educación regulamentada -o que non afectou aos seus irmáns-, non significou a exclusión doutro tipo de educación, a intrafamiliar, que, no seu caso, veu da man dunha tía solteira que reunía na súa casa a un grupo de nenas ás que ensinaba doutrina e fiado. Partindo destas bases formativas, a Monxiña do Penedo chegaría a relacionarse coa máis alta sociedade madrileña, incluso coa raíña dona Bárbara de Bragança, antes de retornar a Galicia para poñer en marcha o seu proxecto de fundar un convento carmelita en Compostela ${ }^{75}$.

María Antonia, sobre a que dispomos dun par de biografías de corte erudito e encomiástico $^{76}$, non foi nin a primeira monxa que escribiu na Galicia do Antigo

\footnotetext{
74 Vid. http://www.autoresgalegos.org/web/asp/contenido.asp?seccInt=1\&pag=6\&idAutor=205\# [Consulta: 23/04/2011].

75 O. Rey Castelao e S. Rial García, Historia das mulleres..., páxs. 211-213 e 243-245.

${ }^{76}$ La Venerable madre María Antonia de Jesús: una mística gallega en el siglo XVIII: fundadora del Convento de Carmelitas de Compostela por una Carmelita Descalza de Convento de Santiago, Fundación Pedro Barrié de la Maza, A Coruña, 1991 e Evaristo de la Virgen del CARMEN (O.C.D.), La Monjita del Penedo: Vida de la Venerable Madre María Antonia de Jesús, Fundadora del Con-
} 
Réxime nin logrou pasar do manuscrito á letra impresa. Pola contra, dona Isabel Rodríguez, relixiosa da comunidade de clarisas de Allariz, si chegou a publicar unha glosa entre o conxunto de textos impresos en Santiago, no ano de 1697, con motivo das Fiestas Minervales celebradas na honra do arcebispo Fonseca. O nivel de alfabetización, a dispoñibilidade de tempo e a procura de auto-realizarse individual e socialmente son algúns dos factores que posiblemente contribuíron ao desenvolvemento dunha literatura escrita por monxas, moitas veces en forma de textos autobiográficos ${ }^{77}$.

Finalmente, podemos citar a dúas mulleres do século XVIII que destacaron polas súas inquedanzas intelectuais: dona María Francisca de Isla y Losada, irmá do Padre Isla, autor da Historia del famoso predicador fray Gerundio de Campazas (1750), e dona María Reguera y Mondragón. Esta última exemplifica a tímida e non sempre fácil apertura das Asociacións, Sociedades e Academias ás mulleres ilustradas ${ }^{78}$. No caso de dona María permitíuselle participar nalgunhas actividades da "Sociedad Económica de Amigos del País de Lugo", sen que esta sociedade permitise a incorporación de socias femininas no século XVIII. Entre as súas contribucións á cultura impresa convén destacar dous discursos dedicados á educación popular, que foron publicados en Madrid no Memorial literario. Ademais, dona María foi autora dun método de escritura innovador ${ }^{79}$.

O alto nivel cultural da fidalga María Francisca de Isla y Losada (17341808), cuxo pai se ocupaba de administrar o patrimonio da casa de Altamira, permitiulle desenvolver unha intensa actividade intelectual pola que recibiu os alcumes de perla galega e musa compostelá. Integrada nos círculos culturais da "Compostela da Ilustración", as relacións de dona M ${ }^{\mathrm{a}}$ Francisca incluían nomes como o arcebispo don Francisco Bocanegra, o cura de Fruíme don Diego Antonio de Cernadas y Castro ou o escritor e académico da Real Academia de la Historia don José Cornide Saavedra ${ }^{80}$. Ademais, esta muller acadou unha formación excepcional que lle permitiu realizar as súas propias obras, esencialmente

vento de Carmelitas Descalzas de Santiago de Compostela, Santiago-Madrid, Seminario C. Central e Espiritualidad, 1931-1948, 2 vols.

77 James S. Amelang, “Autobiografías femeninas”, en Isabel Morant (dir.), Historia de las mujeres en España y América Latina, II. El mundo moderno, Madrid, Cátedra, 2005, páxs. 155-168.

78 Xosé Luís BARREIRo BARREIRo "Ilustración, censura e reivindicación das mulleres. Vicente do Seixo (1747-1802)", en Xosé Luís Barreiro Barreiro, Luís Rodríguez Camarero e Martín GonZÁlez FernándeZ (coords.), Censura e Ilustración. XX Aniversario da Fundación da Facultade de Filosofía e CC. da Educación, Santiago de Compostela, Universidade de Santiago de Compostela, 1997, páxs. 126-128.

79 J. D. Fernández Fraga, Lugo, siglo XVIII..., páx. 306.

${ }^{80}$ Carlos García Cortés, María Francisca de Isla y Losada (1734-1808): una conexión literaria en la Compostela de la Ilustración, Santiago de Compostela, Instituto de Estudos Galegos "Padre Sarmiento", 2008, páxs. 202-223. 
poesías -algunha tamén en lingua galega-, corrixir os sermóns de don Francisco Bocanegra para envialos á imprenta ou preparar a edición das obras do seu irmán.

O caso de dona María Francisca de Isla y Losada achéganos a outra das diversas relacións que se poden establecer entre as mulleres e a produción impresa: o "madroado" ou, cando menos, o impulso de difundir determinados textos a través da imprenta. Lamentablemente, non dispoñemos de datos suficientes para profundar nesta realidade aplicada ao caso galego ${ }^{81}$. De todos modos, sabemos que dona María Francisca si impulsou a impresión de obras como a tradución da Arte de encomendarse a Dios, o sea virtud de la oración, do pai Antonio Francisco Bellati, ou as Reflexiones cristinas sobre las grandes verdades de la fe y sobre los principales misterios de la Pasión de Nuestro Señor Jesucristo. Mais como herdeira e irmá do Padre Isla, a súa gran empresa foi a edición das Cartas familiares deste, así como algúns dos seus sermóns. En 1803, apareceu a biografía del, Compendio histórico de la vida, carácter moral y literario del famoso padre José Francisco de Isla, sobre a que existe a sospeita dunha posible autoría de dona María Francisca ${ }^{82}$. Non obstante, en xeral atopamos moi poucos datos sobre a autoría feminina na Galicia moderna, ademais de estarmos nun contexto no que unha parte considerable da produción de autores galegos sería canalizada a través de imprentas foráneas, sobre todo, de Madrid, que, por suposto, non se caracterizaron, precisamente, por facilitar a divulgación das voces e palabras femininas ${ }^{83}$.

Finalmente, só nos queda sinalar que, sen probarse unha participación feminina activa, documéntanse varios impresos que foron dedicados a determinadas señoras. Non sabemos se existe algún tipo de relación de "madroado" ou mecenado feminino directo, posiblemente, pero, cando menos, permítennos coñecer algo máis sobre a rede de relacións que xurdiron entre as mulleres e os produtores de textos no marco da imprenta galega ${ }^{84}$.

\footnotetext{
${ }^{81}$ Non obstante, si contamos con algunhas noticias dispersas. Así, está documentado que Luís de Paz imprimiu en Santiago, no ano 1605, as Constituciones de Nuestra Señora de la Lavra de la orden de sancto Domingo (...) a instancia de doña María de Toledo y Coloma, Duquesa de Alba, fundadora [a negriña é nosa]. Vid. Atanasio LópeZ, La imprenta en Galicia. Siglos XV-XVIII, Santiago de Compostela, Xunta de Galicia, 1987, páxs. 90-91.

${ }^{82}$ Sobre o labor editor desta muller véxase C. GARCía CoRTés, María Francisca de Isla y Losada..., páxs. 271-292.

${ }^{83}$ O. Rey Castelao e S. Rial García, Historia das mulleres..., páxs. 246-249.

${ }^{84}$ A modo de exemplo podemos sinalar o Sermón fúnebre en las Honras del Excelentíssimo Señor Don Pedro Juan Luis de Zúñiga, Marqués de Aguilafuente, Governador y Capitán General de Galicia (...) dedicada a la Excelentissima Señora Doña Teresa de Velasco y Mendoza, Marquesa de Aguilafuente, impreso en Santiago por José do Canto, en 1668. Neste caso é fácil sospeitar dun encargo de dona Teresa para honrar ao seu defunto marido. O mesmo esquema repítese na Ora-
} 


\section{CONCLusións}

Tras este percorrido breve e xenérico por algunhas das complexas relacións que se estableceron entre as mulleres e a cultura letrada na Galicia dos séculos XVI, XVII e XVIII (particularmente no que se refire ao mundo da produción impresa), podemos concluír que non resulta fácil aprehender estas relacións en tódalas súas dimensións e detalles. No estado actual das investigacións, e unha vez consolidada a perspectiva de xénero e a historia cultural no marco da historiografía modernista galega, cómpre sinalar que aínda quedan por estudar en profundidade moitas cuestións en relación con este acceso das mulleres ao mundo do escrito e do impreso.

Ademais de entrar en xogo a diferenza sexual -perceptible nas taxas de alfabetización e escolarización que nos indican o número de lectores en potencia-, a relación entre as mulleres e os impresos galegos estivo condicionada por factores como a renda, a pertenza a un ou a outro grupo socio-profesional e o lugar de residencia -rural/urbano ou interior/costa-. Neste sentido, non podemos esquecer que estamos ante unha poboación maioritariamente rural e con escasas posibilidades económicas.

Ao longo do presente traballo puidemos comprobar como o acceso das mulleres á lectura da produción impresa saída dos talleres galegos -fundamentalmente composteláns-, estivo limitada, en primeiro lugar, polas baixas taxas de alfabetización feminina existentes na Galicia do Antigo Réxime. Esta realidade non é allea a outros moitos lugares nun contexto no que se cría, maioritariamente, que as mulleres eran inferiores aos homes física e intelectualmente. Só algunhas voces foron as que reclamaron melloras para a educación feminina, o que moitas veces se entendía en clave de formación relixiosa e non de aprender a ler, escribir e contar.

A pesar de que ao longo do período estudado si hai indicios dun progresivo desenvolvemento da capacidade lecto-escritora das mulleres, os diferentes estudos existentes poñen de manifesto a persistencia do analfabetismo feminino.

ción fúnebre en las Honras, que celebró en el Colegio de la Compañía de Jesús de la Coruña (...) al Excelentíssimo Señor Marqués de San Vicente, Virrey, y Capitán general (...) y la dedica a la Excelentíssima Señora Marquesa de San Vicente, Esposa de su Excelencia, impresa en Santiago por Jacinto do Canto, en 1703. Máis alá das oracións fúnebres temos outros exemplos como o Padrón festivo de el Carmen empadronado en la Ilustra Villa de Iria Flavia. Relación epicena en verso, y prosa joco-seria de Noche, y de Día de la Solemnidad, con que se dedicó al Gloriosíssimo y Puríssimo Esposo de María Santíssima, el Patriarca San Joseph, la nueva Iglesia de los Rmos. Padres Carmelitas Descalzos de Padrón (...) dicha Religiosíssima Comunidad la dedica a la muy Ilustre señora Doña Josepha de los Bobos Sarmiento y Bolaño, Marquesa de Parga, Condesa de Amarante, Vizcondesa de Junquera, \&c. Patrona de dicha nueva Iglesia, y Convento, publicado en Santiago por Andrés Fraiz, ca. 1753. 
Consecuentemente, o número de lectoras potenciais - de por si máis amplo que o de lectoras reais-é limitado.

Tamén comprobamos como a posesión de libros non supón a súa lectura. Isto dificulta coñecer ese número de lectoras reais que tanto nos interesaría, xa que as fontes dispoñibles, basicamente inventarios post-mortem, supoñen unha sobrerepresentación dos grupos sociais privilexiados -aínda que, efectivamente, estes eran os máis alfabetizados- e ocultan as obras de escaso valor ou as lecturas baseadas no préstamo de libros. Non obstante, a bibliografía consultada insiste en que as bibliotecas de mulleres terían un tamaño reducido e que os seus contidos estarían restrinxidos, fundamentalmente, á devoción e ao entretemento.

De todos modos, non saber ler no marco dunha sociedade de analfabetos tampouco implicaba para as mulleres vivir á marxe da cultura escrita. Para achegarse a esta existían outras vías como as lecturas en voz alta no fogar ou no claustro, os sermóns pronunciados dende o púlpito ou a recitación e a lectura públicas, especialmente durante as celebracións de diferentes cerimonias.

Constatouse tamén como as impresoras -e as libreiras, de forma paralelachegaron a selo, sobre todo, por morte dun marido impresor ou por herdanza paterna. Nestas circunstancias, máis que asumir a titularidade permanente das imprentas, as mulleres galegas convertéronse en intermediarias ou en impresoras provisionais, mentres o taller impresor non pasou a un fillo ou a outros sucesores. De feito, ante a presenza masculina, as mulleres tenderon a quedar relegadas a un segundo lugar: sendo o taller impresor unha herdanza paterna, quen asumía na maior parte das ocasións a xestión do mesmo era o marido. Así, sen chegar a negarse a actividade feminina, esta si quedaba subordinada á autoridade masculina.

Poucos datos son os que puidemos atopar sobre a relación entre as mulleres e os impresos en base aos principios de autoría e padroádego/madroádego. As escasísimas galegas que tiveron a capacidade e a oportunidade de crear, practicamente non tiveron repercusión na imprenta e, cando o lograron, non parece ter sido en talleres galegos. Tampouco a práctica da promoción da cultura escrita parece estar moi arraigada entre as mulleres dun territorio como o galego, onde a produción impresa estaba, basicamente, ao servizo dos intereses das autoridades eclesiásticas.

Entre os diferentes procesos que a Inquisición abriu contra as mulleres atopamos algúns relacionados co tema do libro impreso. Porén, non parece que estas fosen un sector especialmente problemático neste sentido.

En definitiva, a través deste traballo puidemos realizar unha primeira aproximación a un tema tan complexo como é o das interrelacións que se deron entre as mulleres e a produción impresa dos séculos XVI, XVII e XVIII, no marco das 
dificultades que se lles presentaron ás mulleres para acceder con normalidade á cultura letrada. Asentadas as bases grazas ás recentes investigacións sobre a alfabetización feminina e sobre a implantación, desenvolvemento e consolidación da imprenta en Galicia, aínda queda por profundar neste tema pese a que as dificultades documentais e a escasa novidade dos resultados, especialmente en cuestións como a análise dos discursos masculinos en clave de xénero, poidan desanimar o seu estudo. Deste xeito, se apostamos por ler con atención os novos materiais que vaian aparecendo e por reler, interrogándoos con novas preguntas, aqueles outros dos que xa dispoñemos seremos capaces de ofrecer novos datos e repostas sobre os temas que aquí anunciamos e, sobre todo, de perfilar mellor o conxunto de relacións que se estableceron entre as mulleres e a cultura. Para iso, convén botar man das fontes que tradicionalmente se empregaron para o estudo da alfabetización (protocolos notariais, fontes fiscais como os padróns e os catastros, fontes eclesiásticas como as visitas pastorais, fondos de instrución pública, actas municipais, fondos de instrución primaria, etc.), pero tamén doutras novas que, sen chegar a convertérense en produtos impresos, permanecen aínda inéditas. Precisamente, o estudo detido dos manuscritos elaborados por mulleres, sexan pequenos poemas, textos longos ou simples cartas, contribuirá en grande medida a coñecer o seu nivel cultura pois, ver a destreza coa que manexaban a pluma -tanto na concepción intelectual do texto como na súa realización física- e non só o estudo cuantitativo dos escritos femininos será fundamental para desentrañar até que punto a realidade era moito máis rica e diversa do que nos fan crer os numerosos tratados que desalentaban a alfabetización e o desenvolvemento da autoría feminina na Época Moderna. Sen entrarmos no debate un tanto estéril do cuantitativo versus o cualitativo, parécenos fóra de toda dúbida que a historia das mulleres debe apostar por analizar con minuciosidade calquera dato ou pequeno indicio sobre as actividades culturais femininas. Ademais, dende unha perspectiva metodolóxica, contribuirá a profundar no estudo deste tema o establecemento dunha intensa colaboración entre os especialistas en historia cultural, os paleógrafos, os historiadores da literatura e, por suposto, os preocupados por estudar a vida e as representacións das mulleres na Galicia moderna en base ao sistema de xéneros que se foi configurando historicamente. A través dun diálogo constante entre eles, a alfabetización e a autoría femininas, así como as posibilidades que tiveron as mulleres para participar no mundo da imprenta como promotoras, artesás ou creadoras, poderán ser estudadas con maior precisión. Ademais, cómpre insistir na necesidade de examinar estas cuestións incorporando non só a perspectiva de xénero, senón tamén a da pertenza a un determinado grupo social ou outro, así como a da localización dos individuos nun determinado territorio - pois as diferenzas entre o mundo rural e o urbano eran especialmente notables e ofrecer un panorama completo sobre a alfabetiza- 
ción feminina para o conxunto da xeografía galega é aínda unha das cuestións pendentes-.

O certo é que, sendo o analfabetismo unha realidade case absoluta, algunhas mulleres galegas chegaron a escribir, producir, vender e ler produtos impresos nos que se representaba unha feminidade fiel á tradición cristiá de esencia contrarreformista. De todos modos, estamos plenamente convencidos de que a cuestión cultural feminina na Galicia do Antigo Réxime non se resolve nin coa simple análise dos impresos realizados en terras galegas, nin cos procedentes doutros lugares. A creación, asimilación e transmisión cultural por parte das mulleres pasa necesariamente por unha redefinición e aclaración do termo "cultura" e de tódalas súas implicacións. Ademais, a operatividade da dicotomía existente entre "cultura popular" e "cultura culta" ou entre "cultura letrada" e "cultura oral" é máis que cuestionable para continuar analizando o tema. Dende logo, aínda fican moitas cuestións pendentes para chegarmos a definir, dende a perspectiva feminina, o panorama cultural galego. Un ámbito onde o escrito e, sobre todo, a produción impresa só eran unha parte do conxunto e, ademais, estaban expresados nunha lingua que non se correspondía coa fala das xentes, é dicir, coa súa lingua materna: o galego.

\section{ApÉNDICE GRÁFICO}

Gráfica 1:

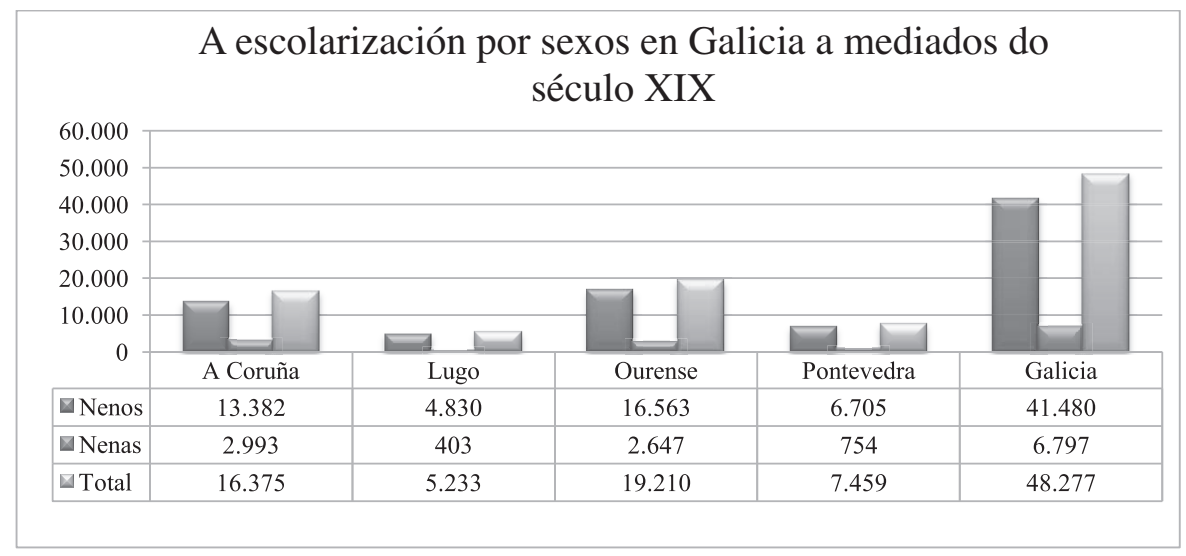

Fonte: Ofelia Rey Castelao, Libros e lectura en Galicia. Siglos XVI-XIX, Santiago de Compostela, Xunta de Galicia, 2003, páx. 61. 


\section{Gráfica 2:}

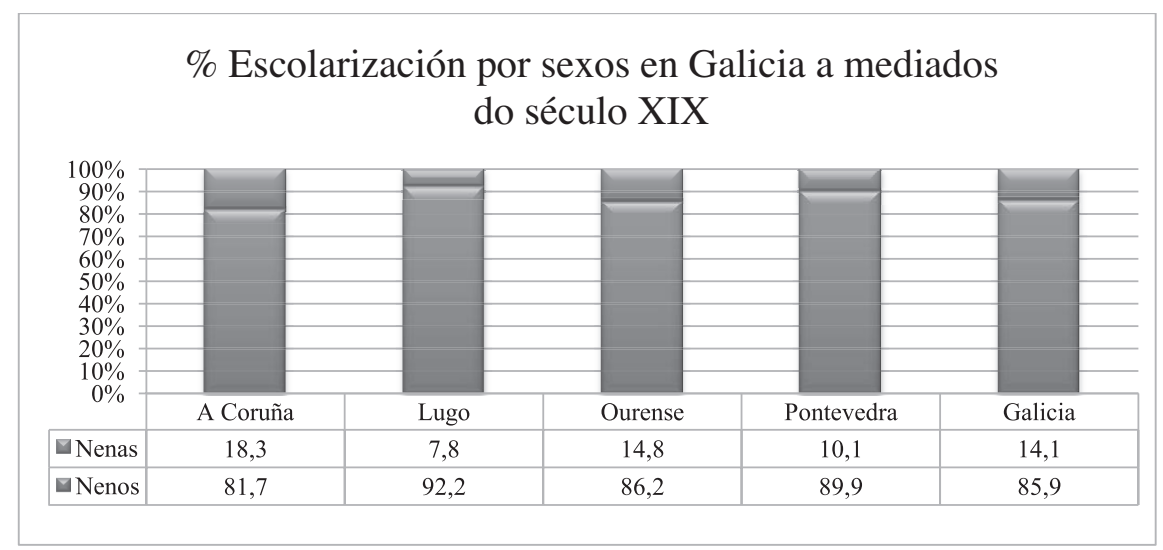

Fonte: Ofelia Rey Castelao, Libros e lectura en Galicia. Siglos XVI-XIX, Santiago de Compostela, Xunta de Galicia, 2003, páx. 61.

Gráfica 3:

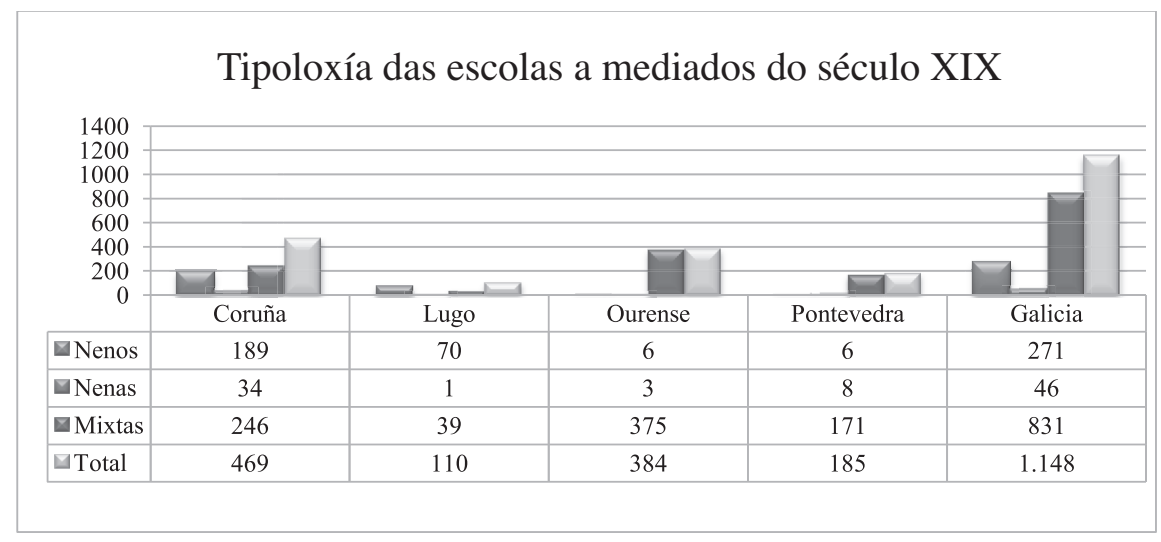

Fonte: Ofelia Rey Castelao, Libros e lectura en Galicia. Siglos XVI-XIX, Santiago de Compostela, Xunta de Galicia, 2003, páx. 61. 


\section{Gráfica 4:}

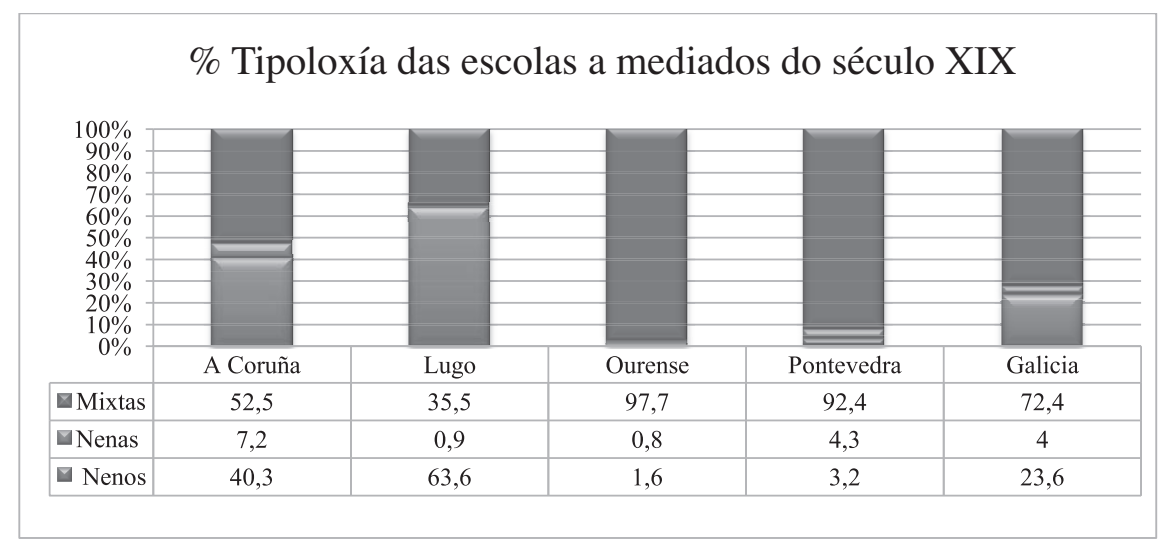

Fonte: Ofelia Rey Castelao, Libros e lectura en Galicia. Siglos XVI-XIX, Santiago de Compostela, Xunta de Galicia, 2003, páx. 61.

\section{Gráfica 5:}

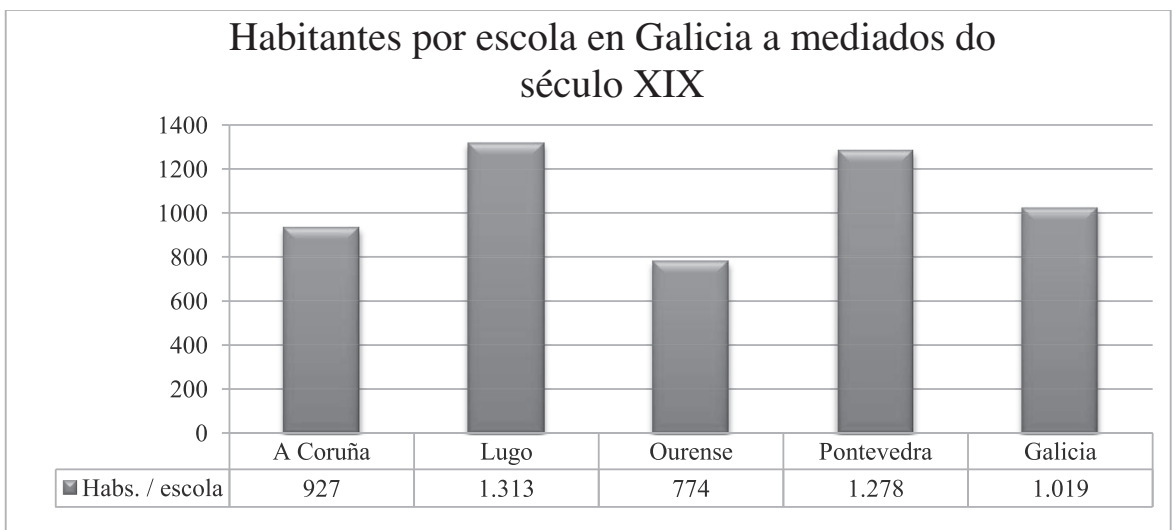

Fonte: Ofelia Rey Castelao, "Niveles de alfabetización en la Galicia de fines del Antiguo Régimen”, Bulletin Hispanique, 100, 2 (1998), páx. 296. 


\section{Gráfica 6:}

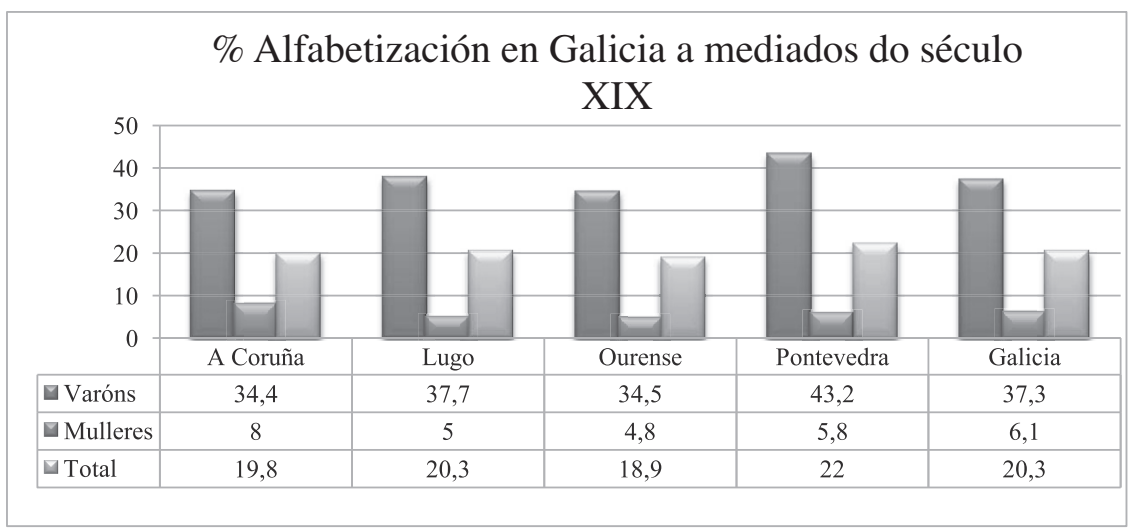

Fonte: Ofelia Rey Castelao, "Niveles de alfabetización en la Galicia de fines del Antiguo Régimen”, Bulletin Hispanique, 100, 2 (1998), páx. 296.

\section{Gráfica 7:}

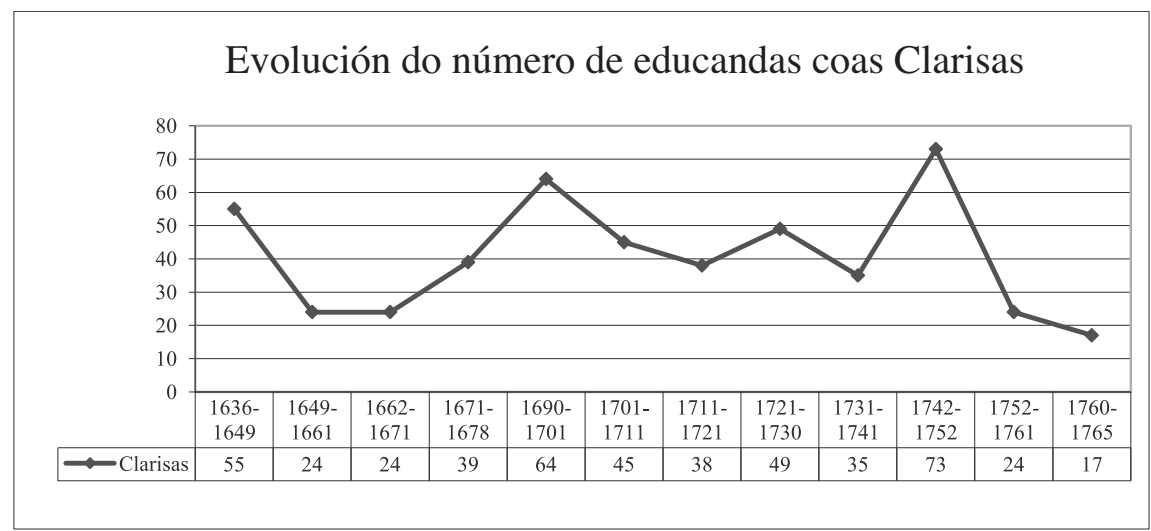

Fonte: Ofelia Rey Castelao e Serrana Rial García, Historia de las mujeres en Galicia (siglos XVI al. XIX), Vigo, Nigratrea, 2009, páx. 255. 


\section{Gráfica 8:}

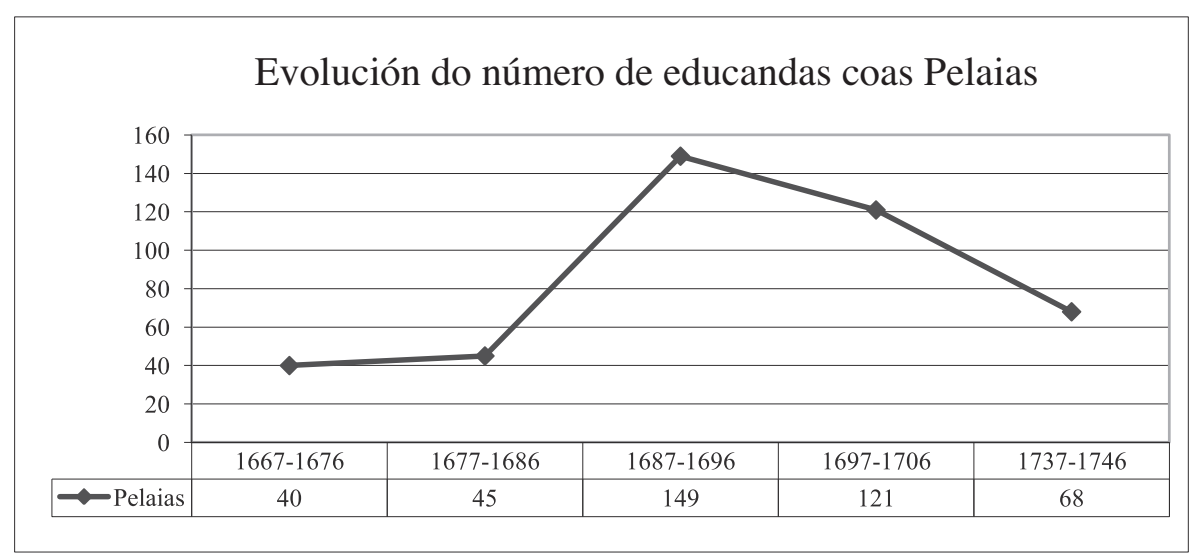

Fonte: Ofelia Rey Castelao e Serrana Rial García, Historia de las mujeres en Galicia (siglos XVI al. XIX), Vigo, Nigratrea, 2009, páx. 255

\section{BIBLIOGRAFÍA}

Barreiro Barreiro, Xosé Luís, "Ilustración, censura e reivindicación das mulleres. Vicente do Seixo (1747-1802)", en Xosé Luís Barreiro Barreiro, Luís Rodríguez Camarero e Martín González Fernández (coords.), Censura e Ilustración. XX Aniversario da Fundación da Facultade de Filosofía e CC. da Educación, Santiago de Compostela, Universidade de Santiago de Compostela, 1997, páxs. 95-138.

Barreiro Mallón, Baudilio, "Alfabetización y lectura en Asturias durante la Edad Moderna", Espacio, Tiempo y Forma. Historia Moderna, 4 (1989), páxs. 115-134.

Barreiro Mallón, Baudilio, "La lectura y sus problemas en el norte de la Península: estado de la cuestión”, Bulletin Hispanique, 99, 1 (1997), páxs. 75-97.

Barreiro Mallón, Baudilio, "Las educandas en clausura: convento o matrimonio", en Raquel Casal, Roberto J. López e José Miguel Andrade (coords.), Galicia monástica: estudos en lembranza da profesora María José Portela Silva, Santiago de Compostela, Universidade de Santiago de Compostela, 2009, páxs. 311-332.

Barriocanal López, Yolanda, El gravado compostelano del siglo XVIII, A Coruña, Fundación Pedro Barrié de la Maza, 1996.

Bolufer Peruga, Mónica, "Historia de las mujeres en la época moderna: selección de la bibligrafía reciente", Cuadernos de Historia Moderna, 19 (1997), páxs. 197-224.

Cátedra, Pedro M. e Rojo, Anastasio, Bibliotecas y lecturas de mujeres. Siglo XVI, Salamanca, Instituto de Historia del Libro y de la Lectura, 2004. 
Costa Rico, Antón, Historia da educación e da cultura en Galicia (séculos IV-XX). Permanencias e cambios no contexto cultural e educativo europeo, Vigo, Xerais, 2004.

Domínguez García, José Manuel, Cátedras de gramática y educación en Galicia, siglos XVI y XVII, A Coruña, Fundación Pedro Barrié de la Maza, 2010.

Dubert García, Isidro, Historia de la familia en Galicia, 1550-1830, Sada, Ediciós do Castro, 1992.

Dubert García, Isidro (coord.), Historia de la Galicia moderna, Santiago de Compostela, Universidade de Santiago de Compostela, 2012.

Fernández Cortizo, Camilo, “A una misma mesa y manteles: la familia en Tierra de Montes en el s. XVIII”, Cuadernos de Estudios Gallegos, 33, 98 (1982), páxs. 237-276.

Fernández Cortizo, Camilo, "Mujer, vejez y grupo doméstico en la Galicia rural meridional a finales del Antiguo Régimen", Nuevo Mundo, Mundos Nuevos [en liña], dispoñible en <http://nuevomundo.revues.org/29553> [Consulta: 12/10/2010].

Fernández Fraga, José David, Lugo, siglo XVIII. Educación e Ilustración, Lugo, Deputación Provincial de Lugo, 1992.

Gallego Domínguez, Olga, Historia da muller. Mulleres ourensás dos séculos XIV-XVIII, Santiago de Compostela, Xunta de Galicia e Grupo Marcelo Macías, 2008.

García Cortés, Carlos, María Francisca de Isla y Losada (1734-1808): una conexión literaria en la Compostela de la Ilustración, Santiago de Compostela, Instituto de Estudos Galegos "Padre Sarmiento", 2008.

García-Fernández, Miguel, "Las Sarmiento: mujeres con poder al final de la Edad Media", en $\mathrm{M}^{\mathrm{a}}$ Isabel del Val Valdivieso e Cristina Segura Graíño (eds.), La participación de las mujeres en lo político. Mediación, representación y toma de decisiones, Madrid, A. C. Almudayna, 2011, páxs. 135-154.

Gelabert González, Juan E., "Lectura y escritura en una ciudad del siglo XVI: Santiago de Compostela", En la España medieval, 6 (1985), páxs. 161-182.

Gelabert González, Juan E., "Niveaux d'alphabétisation en Galice, 1635-1900”, en De l'alphabétisation aux circuits du livre en Espagne, XVIe-XIXe, Paris, Éditions du CNRS, 1987, páxs. 45-71.

González Fernández, Martín, El idioma de la razón. Ilustración e Inquisición en Galicia (1700-1808), Vigo, Nigratrea, 2008.

González Lopo, Domingo L., "La religiosidad femenina en la Galicia de la época moderna", en Xavier Castro e Jesús de Juana (dirs.), A muller na historia de Galicia, Ourense, Deputación Provincial de Ourense, 1995, páxs. 67-91.

Kelly, Joan, “¿Tuvieron las mujeres un Renacimiento?”, en James S. Amelang e Mary Nash (eds.), Historia y género: las mujeres en la Europa moderna y contemporánea, Valencia, Edicions Alfons el Magnánim, 1990, páxs. 93-126.

López, Atanasio, La imprenta en Galicia, Santiago de Compostela, Xunta de Galicia, 1987 (edición facsimilar da publicada en Madrid, Patronato da Biblioteca Nacional, 1953).

López-Cordón, $\mathrm{M}^{\mathrm{a}}$ Victoria, Condición femenina y razón ilustrada: Josefa Amar y Borbón, Zaragoza, Universidad de Zaragoza, 2005. 
La Venerable madre María Antonia de Jesús: una mística gallega en el siglo XVIII: fundadora del Convento de Carmelitas de Compostela por una Carmelita Descalza de Convento de Santiago, Fundación Pedro Barrié de la Maza, A Coruña, 1991.

López López, Roberto J., "María como modelo de comportamiento para las mujeres según las publicaciones religiosas españolas del siglo XVIII", en David González Cruz (ed.), Vírgenes, reinas y santas. Modelos de mujer en el mundo hispano, Huelva, Universidad de Huelva, 2007, páxs. 131-162.

López López, Roberto J. e González Lopo, Domingo L. (eds.), Balance de la historiografía modernista (1973-2001). Actas del VI Coloquio de Metodología Histórica Aplicada (Homenaje al Profesor Dr. D. Antonio Eiras Roel) celebrado en Santiago de Compostela, del 25 al 27 de octubre de 2001, Santiago de Compostela, Xunta de Galicia, 2003.

Martín García, Alfredo, Auge y decadencia: desarrollo económico, cultura y educación en Ferrolterra durante el Antiguo Régimen, A Coruña, Fundación Pedro Barrié de la Maza 2008 .

Morant, Isabel (dir.), Historia de las mujeres en España y América Latina. II. El mundo moderno, Madrid, Cátedra, 2005.

Odriozola, Antonio e Barreiro, Xosé Ramón, Historia de la imprenta en Galicia, A Coruña, Biblioteca Gallega, 1992.

Pallares Méndez, María del Carmen, Historia das mulleres en Galicia. Idade Media, Santiago de Compostela, Xunta de Galicia e Nigratrea, 2011.

Pedraza-Gracia, Manuel José, "Las mujeres en la imprenta hispana durante los siglos XV y XVI", en Concepción García Caro e Josefina Vílchez Pardo (coords.), Estudios de documentación dedicados a su memoria. Homenaje a Isabel de Torres Ramírez, Granada, Universidad de Granada, 2009, páxs. 587-605.

Pizán, Cristina de, A cidade das mulleres, Santiago de Compostela, Xunta de Galicia, 2004.

Rey Castelao, Ofelia, "Mujer y sociedad en la Galicia del Antiguo Régimen”, Obradoiro de Historia Moderna, 3 (1994), páxs. 51-69.

Rey Castelao, Ofelia, "Niveles de alfabetización en la Galicia de fines del Antiguo Régimen", Bulletin Hispanique, 100, 2 (1998), páxs. 271-311.

Rey Castelao, Ofelia, Libros e lectura en Galicia. Siglos XVI-XIX, Santiago de Compostela, Xunta de Galicia, 2003.

Rey Castelao, Ofelia, "A cultura escrita en Galicia. Séculos XVI-XVIII", en Pablo Sánchez Ferro (dir.), Entre liñas: unha ollada á historia da cultura escrita en Galicia. Da Idade Antiga ao século XVIII, Vigo, Universidade de Vigo, 2006, páxs. 79-121.

Rey Castelao, Ofelia, "Las mujeres en la Galicia de la Edad Moderna: algunas consideraciones sobre su estudio", en Carlos Andrés González Paz (ed.), As voces de Clío: a palabra e a memoria da muller na Galicia, Santiago de Compostela, Instituto de Estudos Galegos "Padre Sarmiento", 2009, páxs. 65-86.

Rey Castelao, Ofelia, "La historia de las mujeres en Galicia: un estado de la cuestión (19882008)", Minius, 17 (2009), páxs. 191-234.

Rey Castelao, Ofelia, "Amour divin et amour mondain: l'espérience des femmes mariées et des veuves en religion dans la Galice moderne", en Maurice Daumas (dir), Amour divin, 
amour mondain dans les écrits du for privé de la fin du Moyen Âge à 1914, Pau, Cairn, 2011, páxs. 237-254.

Rey Castelao, Ofelia, "Las mujeres en la Galicia moderna: lo que sabemos y no sabemos de ellas", en Miguel García-Fernández, Silvia Cernadas Martínez e Aurora Ballesteros Fernández (eds.), As mulleres na Historia de Galicia. Actas do I Encontro Interdisciplinar de Historia de Xénero, Santiago de Compostela, Andavira, 2012, páxs. 117-139.

Rey Castelao, Ofelia e Rial García, Serrana, Historia de las mujeres en Galicia (siglos XVI al XIX), Vigo, Nigratrea, 2009.

Rey Castelao, Ofelia e Rial García, Serrana, Historia das mulleres en Galicia. Idade Moderna, Santiago de Compostela, Xunta de Galicia e Nigratrea, 2010.

Rial Costas, Benito, Producción y comercio del libro en Santiago (1501-1553), Madrid, Calamur, 2007.

Rial García, Serrana, "Casar doncellas pobres, paradigma de la caridad eclesiástica”, Obradoiro de Historia Moderna, 3 (1994), páxs. 71-85.

Rial García, Serrana, Mujer y actividad económica en la Galicia moderna: la inserción de las mujeres en la producción económica rural y urbana, [CD Rom], Santiago de Compostela, Universidade de Santiago de Compostela, 2003.

Rial García, Serrana, "Solas y pobres: las mujeres de las ciudades de Galicia ante la marginalidad y la pobreza", Semata, 16 (2004), páxs. 301-331.

Rodríguez Núñez, Clara Cristela, Los conventos femeninos en Galicia. El papel de la mujer en la sociedad medieval, Lugo, Deputación Provincial de Lugo, 1993.

Saavedra Fernández, Pegerto, A vida cotiá en Galicia de 1550 a 1850, Santiago de Compostela, Universidade de Santiago de Compostela, 1992.

Sánchez Rodríguez, María José, La enseñanza de las letras en la educación de la mujer española (siglos XIII-XIX), Granada, Universidade de Granada, 2003, tese de doutoramento inédita [en liña], dispoñible en http://hdl.handle.net/10481/4626.

Sanz González, Margarita, “Alfabetización y escolarización en Galicia a fines del Antiguo Régimen”, Obradoiro de Historia Moderna, 1(1992), páxs. 229-249.

Sanz González, Margarita, "La Compañía de María en Galicia desde fines del Antiguo Régimen hasta la Primera República", en Actas del I Congreso Internacional del monacato femenino en España, Portugal y América. 1492-1992, León, Universidad de León, 1993, tomo II, páxs. 587-601.

Sonnet, Martine, "La educación de una joven", en Georges Duby e Michelle Perrot (dirs.), Historia de las mujeres. 3. Del Renacimiento a la Edad Moderna, Madrid, Taurus 2006 ( $1^{a}$ ed. en castelán 1993), páxs. 142-179.

Virgen del Carmen, Evaristo de la (O.C.D.), La Monjita del Penedo: Vida de la Venerable Madre María Antonia de Jesús, Fundadora del Convento de Carmelitas Descalzas de Santiago de Compostela, Santiago-Madrid, Seminario C. Central e Espiritualidad, 19311948, 2 vols.

Weruaga Prieto, Ángel, Lectores y bibliotecas en la Salamanca moderna. 1600-1789, Salamanca, Junta de Castilla y León, 2008. 